\title{
A Neighborhood-Level View of Riots, Property Values, and Population Loss: Cleveland 1950-1980 \\ by
}

William J. Collins and Fred H. Smith

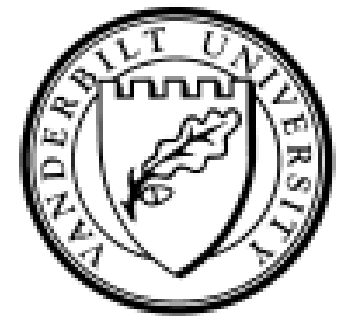

Working Paper No. 05-W28

November 2005

DEPARTMENT OF ECONOMICS

VANDERBILT UNIVERSITY

NASHVILLE, TN 37235

www.vanderbilt.edu/econ 


\title{
A Neighborhood-Level View of Riots, Property Values, and Population Loss: Cleveland 1950-1980
}

\author{
William J. Collins and Fred H. Smith
}

\author{
November 2005 \\ Revised Version of Paper Prepared for the \\ Social Science History Association Meetings in Portland
}

Contact Information: william.collins@vanderbilt.edu; frsmith@ davidson.edu.

Collins is Associate Professor of Economics at Vanderbilt University and Research Associate at the National Bureau of Economic Research. Smith is the MacArthur Assistant Professor of Economics at Davidson College. The authors acknowledge helpful suggestions from Jeremy Atack, Thomas Maloney, Robert A. Margo, and participants at the Social Science History Association Annual Meeting (2005). They also appreciate Gregg Carter's willingness to share his data on riots. Rachel Ahlum, Emily Boleman, Jessica Ford, and Dustin Worley provided excellent research assistance. 


\section{Introduction}

Forty years after the most intense and widespread wave of riots in American history, the economic significance of the events is still largely unexamined. ${ }^{1}$ There is an extensive social science literature about the 1960s riots' causes and patterns of occurrence (see, inter alia, Wanderer 1969; Spilerman 1970, 1971, 1976; Carter 1986; Myers 1997), but the literature on the riots' effects on urban economies is comparatively thin (Aldrich and Reiss 1979, Kelly and Snyder 1980, Collins and Margo 2004a,b). Moreover, the existing "cause" and "effect" studies tend to emphasize cross-city comparisons that forego neighborhood-level perspectives on the riots' legacy.

In this paper, we undertake a case study of riots in the context of Cleveland's economic decline between 1950 and 1980. The case-study framework allows us to pay close attention to local patterns of economic change in the wake of the riots. In essence, we make econometric and graphical comparisons across neighborhoods within Cleveland, conditional on an array of preexisting trends and characteristics, to make inferences about how the riots' impact radiated through the city. ${ }^{2}$ We believe this adds a valuable level of detail to the existing cross-city literature on riots and, more generally, to the literature on the economic history of race, segregation, and economic change in American cities (Wilson 1987; Massey and Denton 1993, Cutler, Glaeser, and Vigdor 1999).

Cleveland was among the largest cities in the United States in 1960, and it was subject to the same forces of de-industrialization and de-centralization that affected many cities in the post-war period. It was also the scene of severe riots in some, but not all, of its predominantly black neighborhoods in the 1960s. Our empirical perspective emphasizes differential changes in property values and population across census tracts depending on their proximity to the riots' epicenter. In

\footnotetext{
${ }^{1}$ For journalistic impressions, see the recent exchange about the 1965 Watts riot in the Washington Post by Roger Wilkins (2005) and John McWhorter (2005), or Ze'ev Chafets on post-riot Detroit in the New York Times (1990).

${ }^{2}$ Census "tracts" are the closest official statistical unit to a "neighborhood", and we tend to use the terms interchangeably. Tracts typically include about 4,000 persons and are separated from one another by major roads,
} 
this context, residential property value is an especially useful variable because it captures a wide range of factors that influence the relative desirability of particular locations.

We find patterns of property value change and population loss that are consistent with concentrated, negative, and long-lasting effects from the 1960s riots. These estimates do not depend on whether we use a narrow or a broad categorization for "riot tracts", whether we use simple difference-in-difference measures or detailed information on the distance of each tract from the riot center, or whether we use ordinary least squares or matching estimation techniques. Moreover, the negative relationship between riots and property value trends is not merely a reflection of the preexisting trend in value, the pre-riot racial composition of the neighborhoods, the pre-riot proportion of neighborhood residents holding manufacturing jobs, the neighborhood crime rate, nor changes in the observable characteristics of the housing stock. Furthermore, to the extent that school desegregation efforts may have influenced property values within Cleveland, we argue that it should have worked against our finding strong riot effects on property values at the neighborhood level.

Our study of differential trends in population across tracts reveals that concentrated property devaluation and concentrated depopulation went hand in hand between 1960 and 1980. The city's East Side neighborhoods experienced significantly larger losses of residential population than other neighborhoods, even in regressions that control for each tract's pre-riot population growth trend, the pre-riot black proportion of the population, and the homicide rate in 1980.

To be sure, Cleveland's economic difficulties did not start with the riots. Rather, we suggest that the impact of the riots was compounded by long-run forces that were already eroding Cleveland's economic base. In this case, it appears that collective violence in the context of an already beleaguered local economy proved doubly devastating to particular parts of the city.

natural boundaries (e.g., rivers or streams), train tracks, and so on. Boundaries do change on occasion, but for the most part they are fixed over the period under study in Cleveland. 


\section{Historical Context: Cleveland and the 1960s Riots}

\section{Long-Run Population Trends}

Population change is a commonly referenced indicator of a city's economic fortunes. It has the benefit of being consistently and transparently compiled, and more importantly, because differences across cities in population growth are driven primarily by migration patterns, population trends reveal information about the relative economic attractiveness of places (Glaeser, Scheinkman, and Shleifer 1995). By this metric, the last fifty years have been unfortunate for the city of Cleveland, though not necessarily for other parts of the metropolitan area.

Figures 1A and 1B chart the population level and population change in Cleveland and in the “non-city" part of Cuyahoga County from 1930 to $2000 .{ }^{3}$ In figure 1A, Cleveland's population level is fairly flat from 1930 to 1950 , reaching its peak level at 915,000 in 1950, at which time Cleveland was the sixth largest city in the U.S. During the 1950s, the city lost some residents (a decline of about 40,000), but at the same time, the population grew rapidly in the suburbs of Cuyahoga County (by about 297,000). The growth of the suburbs was not merely a reflection of migration out of the city; rather, the suburbs were also drawing many new residents from outside the area. In this sense, the local economy was faring well, at least in comparison with subsequent decades.

The disparity between the central city and nearby suburban population growth continued in the 1960s. Cleveland lost 125,000 residents while the suburbs gained 198,000; again, on net, the county gained population during the 1960s, but at a slower rate than in the 1950s. During the 1970s, Cleveland lost 177,000 residents, nearly 24 percent of its total 1970 population, and the county's total population declined for the first time in the twentieth century. ${ }^{4}$ Since 1980 , Cleveland's population and the county's population have continued to drift downward, albeit at a much less

\footnotetext{
${ }^{3}$ Cleveland is located entirely within the confines of Cuyahoga County.

${ }^{4}$ See Galster (1990) for an investigation of white outmigration from Cleveland in the 1970s. The US District Court for the Northern District of Ohio implemented a school desegregation plan for Cleveland in the fall of 1979, although the original decision was announced in Reed $v$. Rhodes in 1976. We discuss the potential influence of school desegregation below.
} 
dramatic pace than in the 1960 s or 1970s. The net result is that the county's total population count was nearly the same in 2000 as it was in 1950, but the share of the county's population residing in Cleveland declined significantly, from 66 to 34 percent.

Overall, the most striking features of figures 1A and 1B are the sharp decline of Cleveland's population in the 1960s and 1970s, and the sharp rise of the rest of Cuyahoga's population during the 1950s and 1960s. In his description of Cleveland's population loss relative to the surrounding suburbs, Bier (1995) emphasizes riots in the 1960s and school desegregation in the 1970s, in combination with federal policies that favored suburban development. But he does not attempt to quantify the impact of the disruptive events, and so it is difficult to form a sense of just significant the events were. One might suggest, for example, that riots were merely highly visible symptoms of the underlying process of urban decline. In this paper, we are especially interested in discovering whether or not the riots left a lasting imprint on the spatial distribution of the city's property values and residential population, and, if so, in measuring the size of the riots' impact. After briefly describing the riots themselves, we discuss our strategy for measuring their effects in section 3 .

\section{Riots in the 1960s}

Starting in the mid-1960s, riots erupted in predominantly black neighborhoods across the United States. A database of race-related "civil disturbances" from 1964 to 1971 chronicles more than 700 violent events that occurred in cities of all sizes and in every region of the United States (see Spilerman 1976 and Carter 1986 for further discussion of the data). According to Gregg Carter's (1986) dataset, five separate civil disturbances occurred in Cleveland between 1964 and 1971. Three of the disturbances were minor events, but two were large scale riots: the Hough riot of July 1966 (in which four persons were killed) and the Glenville Shootout of July 1968 (in which ten 
persons were killed). ${ }^{5}$ Comparing the first and second columns of table 1 reveals that although more people died in the 1968 riot, by all other measures the 1966 riot was a more severe event. A simple index of riot severity that combines information on persons killed, injured, and arrested, as well as instances of arson and days of rioting from 1964 to 1971 suggests that the Hough riot was approximately twice as severe as the Glenville Shootout. ${ }^{6}$

Table 1 also provides summary statistics that compare Cleveland with other large cities (those with populations above 500,000 in 1960). The riots that occurred in Cleveland were not unusual in terms of days of riots or number of injuries, but they were severe in terms of deaths, arsons, and arrests. Overall, the cumulative riot severity index ranks Cleveland in seventh place among all U.S. cities.

The census tracts most heavily affected by the Hough and Glenville riots are outlined in figure 2. The Hough riot was concentrated in the southwest area of the shaded region, and the entire shaded area was cordoned off during the Glenville riot. In 1960, the tracts in the shaded area were predominantly black ( 72 percent of the population, compared to 17 percent in the other tracts), but there were many predominantly black census tracts outside the shaded area. In fact, 27 census tracts in Cleveland had black populations exceeding 90 percent of the total population, and less than half of such tracts are in the area shaded in figure $2 .^{7}$

The Hough riot started outside the Seventy-Niners' Café, which stood at the corner of Hough Avenue and East $79^{\text {th }}$ Street. On the afternoon of July $18^{\text {th }}$, one of the establishment's owners

\footnotetext{
${ }^{5}$ The other three riots occurred in June 1966, April 1967, and October 1968. They were very small in comparison with the two major disturbances discussed in the text.

${ }^{6}$ The riot index is calculated as follows. Each riot $(\mathrm{j})$ is assigned a value $S_{j}=\sum_{i}\left(X_{i j} / X_{i T}\right)$ where $X_{i j}$ is a component of severity (days of rioting, injuries, arrests, deaths, and arsons) and $\mathrm{X}_{\mathrm{iT}}$ is the sum of $\mathrm{X}_{\mathrm{ij}}$ across all riots. The most severe riots were in Los Angeles, Detroit, Washington DC, and Newark. Carter (1986) compiled the base data, and Collins and Margo (2004a) calculated the index. Cleveland's index value is 0.16; the maximum value is 0.52 for Los Angeles.

${ }^{7}$ See Kusmer (1976) for a history of early black settlement patterns in Cleveland.
} 
refused to serve a glass of water to an African-American who had just purchased a pint of wine for "take out" (Lackritz 1968). After being denied the glass of water, the man left the bar and told others in the neighborhood what had transpired. Shortly thereafter, someone posted a sign with a racial slur on the door, attracting a crowd. The seeds for the Hough riot had been sown.

The crowd that gathered around the Seventy-Niners' Café in the late afternoon dispersed into the surrounding blocks of the Hough neighborhood. By the early evening fires had been set in several locations between East $71^{\text {st }}$ Street and East $93^{\text {rd }}$ Street. Looting, vandalism, and random gunfire continued in Hough throughout the evening, and the gunfire caused the riot's first death.

Daybreak on Tuesday the $19^{\text {th }}$ found Cleveland in a state of relative calm, but it did not last long. Looters overran small businesses and shops in Hough throughout the morning, prompting the Mayor Ralph Lochler to call for assistance from the National Guard. Lochler would later be criticized for waiting until 3:30 p.m. to place the call to the National Guard, for the timing of the request meant that National Guard troops did not arrive in Cleveland before sundown. That evening, the events of the previous night were replayed - looting, random gunfire, and arson flared throughout Hough. The fire department battled 40 different fires over the course of the evening, despite resistance from some rioters who cut fire hoses and threw stones and bottles at the firemen. A second death from gunfire occurred as the victim tried to assist his neighbor in boarding up his storefront. Several hundred men from the $107^{\text {th }}$ Armored Regiment of the National Guard arrived in the city and temporarily restored order around 11 p.m. (Lackritz 1968).

At daybreak on the morning of July $20^{\text {th }}$, the National Guard sealed Hough Avenue from $79^{\text {th }}$ to $93^{\text {rd }}$ Street. However, this did not prevent widespread looting in the outlying areas of the neighborhood. Between July 20 and July 25, the riot continued in the neighborhoods of the East Side, with each day following a similar pattern. During the daylight hours, the police and the National Guard would re-establish control over the core of the Hough neighborhood. This pushed 
the looters and arsonists into the outlying areas of Hough, and, eventually, into the surrounding neighborhoods of Kinsman, Glenville, and Central (Lackritz 1968).

The East Side finally returned to "normal" on July 25. In addition to the tangible losses caused by the riot, Clevelanders lost confidence in the city's leaders, and in 1967 Cleveland voters elected an African-American mayor, Carl Stokes. ${ }^{8}$ Voters hoped that Stokes would do a better job of understanding the concerns of the African-American residents who lived on the East Side of the city, and, furthermore, they hoped that he would be able to prevent a reoccurrence of rioting (Miller and Wheeler 1997).

Unfortunately, another round of rioting broke out in the summer of 1968 in the East Side neighborhood of Glenville. In the early evening of July 23, 1968, two city employees arrived in Glenville to tow away an abandoned car. There are conflicting accounts of what transpired next, but the end result is not in dispute - one of the tow truck operators was shot. Almost immediately after the shooting, intense gun battles broke out in three locations on the East Side of Cleveland. The battles pitted Cleveland police against groups of African-Americans, and between 8:30 and 9:30 p.m. several people were killed or injured. Predictably, the gunfire attracted the attention of other East Side residents; by 10 p.m. a large group of people had gathered on Superior Avenue - just a few blocks from one of the most intense gun fights of the evening. As the crowd increased in size, the police decided that it was beyond their ability to control. As happened two years earlier in Hough, the police abandoned the scene and the crowd became violent. The mob moved along Superior Avenue, looting stores, beating a policeman who had failed to escape the area, and starting fires (Corsi and Masotti 1969).

At daybreak on July 24, the situation appeared to have stabilized, but Mayor Stokes and other city leaders were fearful of new outbreaks of violence. Community leaders proposed an "all-black"

\footnotetext{
${ }^{8}$ Stokes was the first African-American mayor of a major American city.
} 
solution to prevent violence on the evening of the $24^{\text {th }}$. Stokes agreed and cordoned off a large area on the East Side surrounding Glenville and Hough - six square miles in total. At the perimeter of this area, Stokes positioned National Guard units and white police officers. ${ }^{9}$ He then ordered African-American police officers and community leaders to form patrols to supervise and safeguard the neighborhoods within the cordoned-off area (Corsi and Masotti 1969).

Stokes' plan managed to prevent any additional deaths, but it failed to prevent arsonists and looters from damaging more East Side businesses and shops. Ten people were killed and dozens were injured in the shootouts and the rioting in 1968. The property damage, however, was much less extensive than the property damage from the Hough riot of 1966. Together the two summers of violence deeply scarred the landscape of Cleveland's East Side. Burned out and abandoned buildings, vacant storefronts, and vacant lots served as constant reminders of the riots. Anecdotal evidence suggests that the riots affected the market for housing in Cleveland, and that the effects were felt most strongly in the areas proximate to the riots (Miller and Wheeler 1997). But the influence of the riots has not been distinguished econometrically from other factors that influenced trends in property values and patterns of population settlement. The remainder of the paper attempts to disentangle and measure the riots' effects.

\section{Riots and Property Values}

The value of a residential property reflects the expected value of the flow of services associated with its ownership, including shelter for the occupants and access to a wide range of local amenities (such as security, proximity to stores, schools, and so on). The magnitude and duration of a destructive event's property-value effect is, a priori, uncertain. People could view the event as a random occurrence that is unlikely to occur again or that is equally likely to occur elsewhere (a

\footnotetext{
${ }^{9}$ Stokes' plan was poorly received by many of the white members of the Cleveland police department. Cleveland residents took a somewhat more favorable view of Stokes' actions: Nearly 60 percent of the respondents in a poll
} 
lightning strike would be an extreme example), in which case one would expect no long-run impact on property values. Alternatively, people could view the event as something more ominous - a piece of new information about future security and other neighborhood amenities that could alter the longrun desirability and value of homes in one place relative to those in places that are perceived to be less at risk. Finally, and pushing in the other direction, the political response to riots could raise and funnel additional public resources into riot-afflicted areas. For example, in the wake of widespread riots in 1967, the federal Kerner Commission Report concluded with a number of ambitious recommendations for improving the quality of life in ghetto neighborhoods.

With similar considerations in mind, Collins and Margo (2004b) estimate city-level riot effects examining the link between changes in median property values and the severity of the riots that occurred in cities across the country. That is, they estimate riot effects primarily by looking across cities. Similar logic may apply within cities, although it is certainly possible that the overall effects of a riot, if any, could spill over from the neighborhoods where the riot actually occurred to other neighborhoods in the same city. For example, if people changed their expectation of the future tax stream (for additional fire and police protection, or for redistributive programs), or if people throughout the city felt less secure than before the riots (even if not especially proximate to the destruction), then the entire city could become a less attractive place to live and do business than before the riot. By focusing on comparisons across tracts within Cleveland, our measures will not reflect these potentially diffuse effects. Instead, we ask whether or not there is evidence consistent with the presence of strongly concentrated effects in the neighborhoods where the riots took place. We can, moreover, estimate whether the riots' apparent effects dissipated gradually with distance from the riot center. 


\section{Data and Empirical Strategy}

The median housing value for each census tract is taken from the published volumes of the federal censuses of housing for 1950, 1960, 1970, and 1980. The "value" variable pertains to owneroccupied single-family housing units, and it includes both the value of land and the structure. ${ }^{10}$ Because some tracts have few owner-occupied units, median values are not always available, but for the vast majority of tracts in Cleveland we observe property value information in each census year.

We start by separating the city into "riot tracts" and "non-riot tracts", and then we estimate the riots' correlation with post-1960 property value trends in two ways. First, we use straightforward ordinary least squares (OLS) techniques to control for pre-1960 property value trends and other relevant tract characteristics and to test whether median values in the riot tracts declined relative to median values of other tracts in Cleveland. Second, we use relatively new matching techniques to form comparisons between tracts that had riots and those that did not. There are several different types of matching estimators, but their common insight is that when there is a binary "treatment" variable (such as being directly affected by a riot), observations can be matched for comparison on the basis of their ex ante likelihood of being treated. This estimated probability of treatment is called the "propensity score", and it is derived from a probit regression in which "riot tract" is a dichotomous dependent variable and each tract's demographic and economic characteristics serve as independent variables. In this case, the idea is to compare each riot-afflicted census tract ("treated" observations) with tracts that had similar likelihoods (based on their observable characteristics) of containing a riot but that ex post did not ("control" observations).

The single best predictor of whether a riot would take place in a particular tract is the black proportion of the tract's population in 1960. We also use the change in the black proportion of tract residents between 1950 and 1960 and the pre-1960 trend in property values to estimate the propensity scores. Rather than comparing a given riot tract with only its "nearest neighbor" (in terms of the 
propensity score), we use a kernel matching technique that uses all untreated tracts to form a weighted comparison group. High weights are assigned to control-group tracts that have propensity scores that are close to that of the treated tract. ${ }^{11}$

In the frameworks just described, the OLS and matching approaches provide descriptions of how relative property values changed within Cleveland depending on whether or not a severe riot occurred in the neighborhood. We can estimate a more detailed pattern of property value change by incorporating measures of distance from the riot-afflicted neighborhoods. Specifically, using latitude and longitude coordinates for the centroids of each census tract, we computed straight-line distances from the center of each tract to the epicenter of the riots. ${ }^{12}$ We selected the intersection of Hough Avenue and East $79^{\text {th }}$ Street as the epicenter. Recall that this is the intersection where the SeventyNiners' Café was situated, the starting point for the 1966 riot. This location is also near the center of the segment of Hough Avenue that was sealed off by the National Guard in 1966. Hough Avenue and East $79^{\text {th }}$ Street was not the center of the disturbance in 1968 , but the intersection is near the area of Superior Avenue where most of the property damaged occurred. In addition, it is near the center of the area that Mayor Stokes cordoned off on the evening of July 24, 1968.

\section{Results}

OLS estimates of the differential change in property values in riot-torn neighborhoods appear in table 2. Panel A assigns "riot tract" status to tracts that were directly affected the 1966 Hough riot,

\footnotetext{
${ }^{10}$ With census data, there is no way to separate changes in land values from changes in the value of structures.

${ }^{11}$ Our results are generally similar when we use nearest neighbor matching with replacement rather than kernel matching, but in columns 1 and 2 the nearest neighbor-based estimates are nontrivially larger in magnitude (e.g., in panel A, -0.29 rather than -0.20 , and -0.38 rather than -0.30 ). In this sense, our choice of the kernel-based approach produces conservative estimates of the riots' effect, potentially biased toward zero. The default procedure in Stata uses a Gaussian kernel and a bandwidth of 0.06. For sensitivity tests, we have re-run all the estimates in panel A of table 3 using an Epanechnikov kernel with bandwidth varying from 0.04 to 0.08 . Results were very similar except for column 4 where the Epanechnikov kernel led to a smaller estimated effect $(-0.22$ rather than -0.31$)$. Becker and Ichino (2002) provide an introduction to the implementation of matching estimators. Rosenbaum and Rubin (1983) is a seminal article in the propensity score literature.
} 
whereas panel B extends the "riot tract" assignment to the much larger area that was cordoned off during the 1968 Glenville Shootout. The results are roughly similar across the two panels and are consistent with a strong, negative, and long-lasting riot effect.

The first column's coefficients are simply the unconditional differences in log median property value trends between riot and non-riot tracts. The difference is -0.39 in panel A, and -0.29 in panel B; that is, median property values increased by 32 (panel A) or 25 (panel B) percent more in the non-riot tracts than in the riot tracts, on average. ${ }^{13}$ The second column's results are from a similar regression specification, but the sample excludes tracts for which pre-1960 trends cannot be calculated (for better comparison with subsequent columns). The key point from comparing columns 1 and 2 is simply that the change in sample composition makes little difference to the riot coefficient. Columns 3, 4, and 5 add controls for the pre-1960 property value trend, the proportion of housing units that were "dilapidated" in 1960, and the black proportion of the tract's population in 1960, respectively. In columns 3 and 4 (for both panels), the riot coefficient remains between -0.32 and 0.35. The implication is that the riot variable's strong negative coefficient in columns 1 and 2 is not merely reflecting some pre-existing relative deterioration of properties in riot tracts. In column 5, when the proportion black is added to the regression, the riot coefficient falls to about -0.2 in both panels. This implies that tracts with higher black proportions were both more likely to have riots (not surprising in this context) and more likely to have slow property value appreciation post-1960. In every case, the riot coefficient is statistically and economically significant.

A different methodological perspective is provided by table 3's matching estimates. In general, the results from the propensity score matching estimators are in line with those from the OLS approach. Again, panel A assigns "riot tract" status to the Hough riot tracts, whereas panel B

\footnotetext{
${ }^{12}$ Longitude and latitude are from the data underlying Cutler, Glaeser, and Vigdor (1999), available at: http://trinity.aas.duke.edu/ jvigdor/segregation/1990trct.txt. To calculate the distance from each centroid to the epicenter of the Hough riot, we use the Haversine formula.

${ }^{13}$ In the text we usually refer to the magnitude of the coefficient (b) on the dummy variable. The associated percentage change is $\mathrm{e}^{\mathrm{b}}-1$ (Kennedy 1981).
} 
extends that status to areas cordoned off during the Glenville shootout. The first three columns restrict the comparison groups to tracts that meet the common support restriction. ${ }^{14}$ The last three columns do not apply the common support restriction, and therefore they use all available tracts for comparison (while assigning relatively high weights to tracts with propensity scores that are close to the propensity score of each riot tract). The propensity scores that underlie the comparison groups in columns 1 and 4 are based on the proportion of the population that was black in 1960, which is a strong predictor of "riot tract" status. In columns 2 and 5, both the black proportion of the population and the pre-1960 trend in proportion black are used to calculated the propensity scores. In columns 3 and 6, each tract's pre-1960 trend in property values is used as a third predictor of riot propensity. The average treatment effect estimates range from -0.12 to -0.31 , and most estimates are between 0.20 and -0.30 , again implying a statistically and economically significant impact of riots on local property value trends.

Simply splitting the city into "riot" and "non-riot" tracts allows a parsimonious description of how trends differed, on average, between the two groups. But the dichotomy might also obscure a great deal of information by ignoring important elements of heterogeneity within the two groups. For example, the experience of a non-riot tract that is a close neighbor to the riot area could be quite different from one that is miles away. To address this issue, we measured the distance from the center of every tract in Cleveland to the corner of Hough Avenue and East $79^{\text {th }}$ Street, the epicenter of the Hough riot, and we used the regressions in table 4 to describe the relationship between distance-from-riot-center and property value trends.

The specifications in table 4 are exactly like those in table 2, except that distance and distance squared are included as explanatory variables rather than the riot tract dummy. ${ }^{15}$

\footnotetext{
${ }^{14}$ The common support restriction omits observations with estimated propensity scores that fall outside the intersection of the supports of the treatment and control groups' propensity scores. See Becker and Ichino (2002) for a discussion.

${ }^{15}$ A specification with a cubic term (in distance) returns similar results and explains no more of the variance.
} 
Throughout the table, property value gains were clearly larger for tracts that were further from the riot center. According to the regression estimates in column 5, for example, homes located a half mile from the riot epicenter had property value gains that were approximately 0.065 log points higher (seven percent) than at the epicenter; tracts three miles away had gains that were $0.34 \log$ points higher (41 percent).

Figure 3A graphs property value changes against distance from the riot center for 1960 to 1980, along with a fitted value curve representing the quadratic relationship of column 1 from table 4. A strong positive relationship between distance-from-riot and property-value appreciation is clearly visible. Figure 3B graphs the same variables for the 1950 to 1960 period - before 1960, there is no evidence of a statistically or economically significant relationship between distance from the riot center and property value changes.

The geographic pattern of change is laid out in figure 4A, essentially a map of Cleveland with latitude on the vertical axis and longitude on the horizontal axis. At the center of each riot tract we have assigned a number that represents the magnitude of property value gains: tracts in the highest quantile of gains are assigned a " 4 " and tracts in the lowest quantile of gains are assigned a " 1 ". The clustering of 1's around the riot center and the gradual fanning out to the 4's as one moves further from the riot center is clear. To check for a pre-existing pattern of trends, figure 4B presents a similar map for 1950 to 1960 . As in figure 3B, there is no evidence of a pre-existing link between property value trends and proximity to the riot location; after 1960, however, the link is strong.

\section{Alternative Hypotheses: School Desegregation, Crime, the Housing Stock, and Deindustrialization}

In 1970, approximately 90 percent of black students in Cleveland attended schools that were at least 90 percent black. Three years later, the National Association for the Advancement of Colored People (NAACP) filed a class action lawsuit alleging that Ohio and Cleveland school 
officials pursued policies that had the "purpose and effect of perpetuating a segregated public school system" (Reed v. Rhodes, 422 F Supp. at 711-712). In 1976, despite a vigorous defense from school officials, Judge Frank Battisti of the U.S. District Court for the Northern District of Ohio ruled in favor of the plaintiffs and announced an intention (though not yet a plan) to implement an active policy of desegregation. The busing plan went into effect for high school students in the fall of 1979 and for elementary students in the fall of 1980 (Henderson 2002).

During the 1970s, the implementation of court-ordered school desegregation plans spread rapidly from the South to central cities in the North and West. In this sense, Cleveland's experience was not at all unusual. ${ }^{16}$ By some measures, the redistribution was highly successful: the racial dissimilarity index across Cleveland's schools (which ranges from 0 to 100 and characterizes the degree of segregation) fell by 65 points after the plan was put into effect (Welch and Light 1987). But Henderson (2002, pp. 460-462) points out that the "conventional wisdom" is that the plan had a significant negative effect on Cleveland's economic prospects because it spurred the outmigration of middle class whites. Henderson also argues that conventional wisdom is wrong in this case.

For the purposes of this paper, the city-wide implications of desegregation are less relevant than the neighborhood-level implications. And from that perspective, school desegregation should work against our finding a strong relationship between proximity to the riot tracts and property value trends between 1960 and 1980. Based on the school-level data underlying the Welch and Light (1987) study of desegregation, it appears that several high schools (and presumably many elementary schools) in the city of Cleveland were nearly all-white and that others were nearly all-black prior to Reed v. Rhodes. The all-black schools were in the vicinity of the riots (where we observe small property value gains) and the all-white schools were generally at the periphery of the city (where we observe comparatively large property value gains). 
If white parents had a preference for predominantly white schools (anecdotal and survey evidence is clearly consistent with this supposition), then the value of white schools should have been capitalized into the property values of homes near those schools before desegregation. The announcement of Reed v. Rhodes (unless it was anticipated before 1960), which effectively loosened the relationship between house location and school racial composition, should have dampened the value of properties near the white schools. It might well be the case that white neighborhoods in Cleveland lost value relative to their suburban white counterparts as a result of school desegregation, a topic worthy of investigation though beyond this paper's scope, but school desegregation does not help explain the within-city patterns evident in figures $3 \mathrm{~A}$ and $4 \mathrm{~A}$.

A more plausible competing hypothesis is that crime rates soared in Cleveland after 1960, that crime was concentrated in the places we designated as riot tracts, and that the riot coefficients are simply picking up the negative impact of crime on property values. Two points are important in this regard. First, one could argue that to some extent the rise in crime was endogenous to the negative impact the riots had on the city. Collins and Margo (2004a), for example, argue that black employment opportunities (especially for young men) declined in cities that had riots, and one can easily imagine that crime would rise under those circumstances. In Cleveland, the major increase in violent crime came after the Hough riot, not before. The number of murders increased from 84 in 1960 (the base year of the property value change calculation) to 307 in 1972 (the peak number) and then declined slightly to $1980 .{ }^{17}$ So, between 1960 and 1972, the number of murders increased by 223. It turns out that 199 of the 223 person increase occurred after 1965 (the last year before the Hough riot), implying that the upward trend in murders after the Hough Riot was much stronger than before (based on a trend from 1955 to 1965 ).

\footnotetext{
${ }^{16}$ An important brake was put on the school desegregation movement, however, in the Supreme Court's decision in Milliken v. Bradley (1974) which essentially restricted desegregation plans to within-city remedies. Outlying suburban districts could not be forced to participate in busing plans (Clotfelter 2004).

${ }^{17}$ The number of murders is reported in the Federal Bureau of Investigation's annual publication of Uniform Crime Reports.
} 
More directly, one can control for the crime rate in each census tract in 1980 to see if the "riot tract" or "distance-from-riot" regression coefficients are undermined. Fortunately, Harrell and Gouvis (1995) collected crime rate data for each census tract in Cleveland and Washington, DC from 1980 to 1990 for a study sponsored by the Urban Institute. From their study, we extracted the 1980 homicide and burglary rates and included them in OLS regressions similar to those in table 2 and table 4. The basic results are reported in table 5 (including additional covariates does not alter the results substantially). Although it is true that higher crime rates in 1980 were associated with smaller property value gains between 1960 and 1980, the "riot tract" coefficients and "distance from riot" coefficients remain large and statistically significant.

Ideally, it would be helpful to have the 1960 crime rates for each tract as well, so that the change in crime could be an independent variable rather than just the 1980 level. Unfortunately, we have not been able to collect comparable tract-level information for 1960 . Nonetheless, we do know the total number of homicides in Cleveland in 1960, and we have tested two alterative estimates of the 1960 tract-level homicide rate: first, a measure that assumes that homicides in 1960 were distributed across tracts in the same proportions as they were in 1980 (but at a much lower overall level); second, a measure that assumes that the relationship between the proportion of total homicides that occurred in a particular tract, the tract's median property value, and the tract's percent black was the same in 1960 as in 1980. This allows an imputation for 1960 based on regression coefficients from the 1980 cross-section of tracts. Using either of these estimates to calculate the change in the homicide rate from 1960 to 1980, and then entering that change in the regressions, has little effect on the riot coefficients reported in table 5 .

To this point, we have not attempted to control for post-1960 changes in the physical stock of housing in each tract (though we have controlled for the proportion of the stock that was dilapidated in 1960). Therefore, we have allowed the riot coefficients to capture differential changes in both the 
housing stock's quality and other neighborhood amenities. If one believes that differential changes in the stock of housing are endogenous to the riots, then the estimates above are reasonable measures of the riot effects. For example, in theory, repairs to existing housing will not be undertaken and new housing units will not be built in places where the market value of the improvements falls below the cost. A negative shock to the demand for housing in a particular area could lead to endogenous deterioration. But in practice, in the wake of a riot, there may be aggressive urban renewal plans, new policies to redistribute income or resources, or efforts to improve public goods in riot-torn areas. Such efforts could wipe out the lower tail of the housing value distribution or boost local amenities, both of which would work against finding large, negative, and long-lasting riot effects. ${ }^{18}$ In any case, it is worth assessing how much, if any, of the differential decline in housing values may be accounted for by changes in the housing stock itself.

We gathered four descriptive measures of changes in the housing stock in each tract, all of which can be observed consistently in 1960 and 1980: the proportion of housing units in 1980 that were built after 1960; the change in the median number of rooms per housing unit (a proxy for size of units); the change in the proportion of housing units that is owner occupied; and the change in the $(\log )$ number of housing units. Table 6 reports regressions of property value changes on the measures of riot proximity and control variables for changes in the housing stock's characteristics in each tract. Adding these control variables tends to lower the magnitude of the riot coefficients, especially the inclusion of the change in the total number housing units (in column 3), but in all the specifications the riot coefficients are economically large and statistically significant. There is, evidently, a correlation between the change in the number of housing units, proximity to riots, and the change in property values, suggesting that riot-afflicted areas experienced unusually rapid

\footnotetext{
${ }^{18}$ In Cleveland, it appears that the major urban renewal projects were already underway before the riots occurred. The Department of Housing and Urban Development (HUD) publication Urban Renewal Projects Characteristics for December 1965 lists seven projects underway in Cleveland: East Woodland, Erieview I, Garder Valley, Gladstone, Longwood, St. Vincent's Center, and University-Euclid. On the basis of the documentation, one cannot tell whether the scope or direction of the projects was influenced by the riots.
} 
housing stock depletion and population loss over the period. ${ }^{19}$

Throughout this section, we have implicitly assumed that de-industrialization affected all tracts in the same manner, or at least that the process affected tracts in a manner that was uncorrelated with proximity to the riots. The connections between a changing industrial structure, labor demand, and tract-specific housing values may be complex, but if de-industrialization affected some neighborhoods more than others after 1960, then one would expect a concentrated decline in property values in neighborhoods that housed relatively large numbers of manufacturing workers in 1960. That is, one would expect manufacturing workers and their neighborhoods to bear the brunt of the decline in manufacturing labor demand. ${ }^{20}$ We took the last column's regression specification from tables 2 and 4, and we added a variable for manufacturing employment in 1960 divided by total population (results not shown in tables). In each case, the size of the riot coefficient is barely affected by the inclusion of the manufacturing variable, and the results for the manufacturing variable are mixed. When the "Hough" or "Hough and Glenville" dummy variables are used to capture the riot effects (as in table 2's specifications), the manufacturing coefficient is negative and economically and statistically significant. ${ }^{21}$ But when distance and distance-squared measure proximity to the riots (as in table 4), the manufacturing coefficient is small and statistically insignificant.

\section{Riots and Population Change}

A striking implication of Cleveland's depopulation is that the city is now much less densely

\footnotetext{
${ }^{19}$ Appendix table 1 reports three regressions in which all of the previously assessed control variables are entered simultaneously. Proximity to the riot area remains a detriment to housing value appreciation. Between 1960 and 1980, Cleveland lost more than 40,000 housing units. See Glaeser and Gyrourko (2005) on the strong correlation between population loss and housing stock deterioration.

${ }^{20}$ Blanchard and Katz (1992), for example, examine labor market adjustments at the state level and find that workers often migrate in response to negative employment demand shocks. This may depress housing values.

${ }^{21}$ Adding manufacturing/population to column 5 of table 2, panel A yields a coefficient of $-1.6(\mathrm{t}-\mathrm{stat}=2.5)$, implying that a one-standard deviation increase in manufacturing/population (0.04) was associated with a $-0.065 \log$ point decline in relative property value, ceteris paribus. Adding the manufacturing variable to column 5 of table 2 ,
} 
populated than it was in 1950. Figures $1 \mathrm{~A}$ and 1B, discussed above, provided a sense of the citywide decline. A closer view is provided by figures $5 \mathrm{~A}$ and $5 \mathrm{~B}$, which are very similar in format to figures $4 \mathrm{~A}$ and $4 \mathrm{~B}$ but that record quartile ranks of log population change (rather than property value change). Figure 5A shows that the tracts in closest proximity to the riots experienced the largest population losses between 1960 and 1980 - the lowest quartile tracts are labeled " 1 " and are clustered around the riot epicenter. The highest quartile tracts (labeled "4") are spread around the city's perimeter. Figure 5B shows that tracts on the perimeter were already gaining population relative to those on the city's interior during the 1950s, but even so the tracts near the riot epicenter were often in the second, third, and fourth quartiles of population gains. Thus, the change in the pattern of population growth rates between the 1950s and the 1960-1980 period is not quite as sharp as the change in the pattern for property values, but there is still evidence that the tracts near the riot areas became less desirable places to live.

Table 7 provides a more precise analysis of the pattern of population loss. The results indicate that $(\log )$ population loss between 1960 and 1980 was strongly correlated with proximity to the riots. Every column controls for the pre-1960 growth trend, and additional control variables include the black proportion of the population in 1960, and the homicide rate in 1980. Columns 1 to 3 use the "Hough riot" designation of riot tracts; columns 4 to 6 use the broader "Hough and Glenville" designation; and columns 7 to 9 use the distance and distance-squared from riot epicenter measure. The results in columns 4 to 6 are not nearly as strong as in the other columns, indicating that Glenville's depopulation was less severe than Hough's. But in general, it is clear that Cleveland's riot tracts lost residents relatively rapidly, even after controlling for pre-existing trends.

panel B yields a coefficient of $-1.3(\mathrm{t}$-stat $=2.1)$. Adding the manufacturing variable to column 5 of table 4 yields a coefficient of -0.08 ( $\mathrm{t}$-stat $=0.22)$. 


\section{Density Functions}

To provide a visual perspective on the pattern of Cleveland's depopulation, we estimated population density functions for 1960 and 1980. This follows a tradition in the urban economics literature that derives from the early monocentric city models developed by Alonso (1964), Muth (1969), and Mills (1972). A simple monocentic model posits a negative exponential relationship between population density and distance from a city's center. This relationship reflects the willingness of city residents to trade off between residential space and commuting costs. For an individual to be willing to incur the costs of commuting to a residence located at a distance from the city center (and, by assumption, the employment center of the city) he or she must be compensated with more spacious housing.

Early attempts to estimate the population density function were very straightforward. Mills (1972), for example, estimated simple density functions with the natural log of population per square mile as his dependent variable and distance as his lone independent variable. As expected, he found that as distance from the city center increased, population density decreased. This was an important first step in empirical work on urban population density, but the shortcomings of the monocentric model - and the associated population density function - became increasingly clear as American cities became less monocentric and more decentralized.

We use a flexible functional form to describe the relationship between census tract location and population density (population per square kilometer) in Cleveland for 1960 and $1980 .{ }^{22}$ The functional form allows the density estimate to vary asymmetrically with distance and direction from the city center at Public Square..$^{23}$ In figures 6A (1960) and 6B (1980), the reader views Cleveland's

\footnotetext{
${ }^{22}$ More recent efforts at modeling urban population density have incorporated sophisticated mathematical techniques using fractals and point pattern analysis. See Anas et al. (1998) for a discussion of models of urban spatial form.

${ }^{23}$ We report the underlying regression results in appendix table 2. Note that our central reference point in these diagrams is not the riot epicenter. Rather, it is the center of the city. Cleveland's center is located in the middle of Public Square. This is the intersection that divides north from south and east from west for postal addresses within the city. See Smith (2003) for discussion of the long-run evolution of center-city Cleveland.
} 
population density directly from the south of city center - the height of the function approximates the density of the population. The dimensions of the box measure the distance east or west of Public Square (on the $\mathrm{x}$-axis positive numbers represent the east side of the city) and the distance north or south of Public Square (on the y-axis positive numbers represent the north side of the city). So, for example, the lower left hand edge of the box is located five miles west and eight miles south of the city center. The riot epicenter is approximately three miles east and a quarter-mile north of city center.

Of course, these are highly smoothed and stylized representations of Cleveland's residential structure, but nonetheless the pictures are revealing. The depression at the graph's center is the central business district; its residential density is low throughout the period under study. But in 1960, the residential districts around the city's center were densely populated, and as one's perspective moves toward the outskirts of the city, the density declines quickly. By 1980, the picture is strikingly different. The density gradient is dramatically flatter, with much less density around the city center and much more at the periphery.

Figure 7 differences the estimated density functions for 1960 and 1980 to depict the change in Cleveland's population density. The change is shown from two different visual perspectives. The top figure is a bird's eye view from above the southeast corner of the box; the bottom figure places the reader directly north of city center (this is a better view than from directly south). The lump in the graph's middle reflects the fact that very few people lived at the center of the city in either 1960 or 1980 (so, there was little change). More importantly, there is a tremendous loss of density on the city's East Side - population density declined by between two and four thousand persons per square kilometer in some locations on the east side of the city. West Side neighborhoods also experienced substantial losses in population density, though the losses were less dramatic than the changes observed on the East Side. The southern outskirts and other peripheral areas fared better. 


\section{Discussion and Conclusion}

Riots were not the primary cause of Cleveland's downward economic trajectory. The city was already losing population during the 1950s (albeit slowly), and its pre-existing economic base was vulnerable to the regional undercurrent of de-industrialization. Nonetheless, in the midst of these changes, the neighborhood-level census data strongly suggest that the riots had an especially negative and long-lasting effect on particular areas of the city.

Areas near the riot epicenter lost economically significant amounts of property value relative to other places in Cleveland. Depending on the regression specification and the estimation technique (OLS or matching), most of our point estimates suggest property value losses between 20 and 30 percent in the riot-area tracts relative to other tracts in the city. In simple graphs and in regressions, there is a clear positive correlation between distance from the riot epicenter and property value appreciation. As mentioned above, according to the regression estimates in table 4 (column 5), homes that were a half mile from the riot epicenter had property value gains that were approximately seven percent higher than at the epicenter; homes three miles away had gains that were 40 percent higher. Thus, it appears that in Cleveland, any efforts to repair, renew, and otherwise raise the quality of life in riot-torn neighborhoods were overwhelmed by the magnitude of the riot effect. These findings are consistent with Collins and Margo (2004b), which argues that riots in the 1960s had negative effects on black-owned property values on the basis of cross-city comparisons, but our empirical perspective is more finely tuned to identify the localized impact of the events.

The riots' impact is also manifested in differential population trends across tracts within the city. Tracts directly affected by the Hough riot and those in close range of the riot epicenter lost residents at a high rate relative to other parts of the city. According to table 7 (column 3), tracts directly affected by the Hough riot lost 34 percent more population than the average non-Hough 
tract. Figures 6 and 7 illustrate the striking implications for the changing density of settlement in the city.

For the sake of causal inference, it is important to ensure that our measures of riot effects are not picking up other contemporaneous factors that had uneven effects across the city and that were correlated with proximity to the riots. To address such concerns we incorporated a broad range of competing variables into our analysis - changes in tract-level crime rates, changes in the observable characteristics of the housing stock, pre-existing trends in value or population, and pre-existing settlement patterns of manufacturing workers - all without dispelling the strong correlation between proximity to riot activity and the relative decline of property values and population. We re-iterate that these within-city measures might well understate the overall, city-wide impact of the riots. If in the wake of the riots people viewed the entire city as a less attractive place to work, live, and invest, then our cross-tract perspective will not fully reflect the effect of that shift in perceptions.

This is the first econometric case study of a city affected by the 1960s riots, and, as with all case studies, its results cannot necessarily be extended to other places and times. ${ }^{24}$ Nonetheless, we think that Cleveland's post-riot experience helps highlight how urban economies absorb adverse localized shocks. In this case, the areas closest to the riots did not bounce back in the riots' aftermath. Rather, the shock appears to have had a long-lasting, negative impact. This effect may have been especially strong in Cleveland's riot-torn neighborhoods because the city's economic fundamentals were already weak - the population was already in decline and manufacturing employment was melting away. Urban housing stocks adjust slowly in the downward direction, as emphasized by Glaeser and Gyourko (2005), and in the context of a general economic decline, a sudden localized drop in perceived neighborhood quality may lead to rapid deterioration, abandonment, and property value erosion. Moreover, it seems likely that the spectacular destruction

\footnotetext{
${ }^{24}$ Comparisons between Cleveland's post-riot experience and the post-riot trends in Miami (1980) and Los Angeles (1992) might be especially interesting in this regard because they occurred under much different historical and
} 
associated with riots (often widely televised) may cement a reputation for violence and mayhem, a reputation that can easily reinforce itself in a declining area of a declining city. 


\section{$\underline{\text { References }}$}

Aldrich, Howard and Albert J. Reiss. 1970. "The Effect of Civil Disorders on Small Business in the Inner City.” Journal of Social Issues 26: 187-206.

Alonso, W. 1964. Location and Land Use. Cambridge, Massachusetts: Harvard University Press.

Anas, Alex, Richard Arnott, and Kenneth Small. 1998. "Urban Spatial Structure.” Journal of Economic Literature 36:1426-1464.

Becker, Sascha O. and Andrea Ichino. 2002. "Estimation of Average Treatment Effects Based on Propensity Scores.” Stata Journal 2: 358-377.

Bier, Thomas E. "Housing Dynamics of the Cleveland Area, 1950-2000.” In Cleveland: A Metropolitan Reader, edited by W.D. Keating, N. Krumholz, and D.C. Perry. Kent, Ohio: Kent State University Press, 1995: 244-259.

Blanchard, Olivier Jean, and Lawrence F. Katz. 1992. "Regional Evolutions.” Brookings Papers on Economic Activity 1992: 1-75.

Carter, Gregg Lee. 1986. “The 1960s Black Riots Revisited: City Level Explanations of Their Severity," Sociological Inquiry 56: 210-228.

Chafets, Ze'ev. 1990. “The Battle Lines Are Clear and Dangerous: The White Suburbs vs. the Black City." New York Times, July 29: SM22.

Collins, William J. And Robert A. Margo. 2004a. "The Labor Market Effects of the 1960s Riots." In Brookings-Wharton Papers on Urban Affairs, edited by W. Gale and J. Pack. Brookings Institution: Washington, DC: 1-46.

Collins, William J. and Robert A. Margo. 2004b. "The Economic Aftermath of the 1960s Riots: Evidence from Property Values.” NBER Working Paper 10493.

Clotfelter, Charles T. 2004. After Brown: The Rise and Retreat of School Desegregation. Princeton, NJ: Princeton University Press.

Corsi, Jerome R. and Louis H. Masotti. 1969. Shoot Out in Cleveland: Black Militants and the Police - July, 23 1968. New York, NY: Frederick A Praeger Publishers.

Cutler, David M., Edward L. Glaeser, and Jacob L. Vigdor. 1999. "The Rise and Decline of the American Ghetto." Journal of Political Economy 107:455-506.

Department of Housing and Urban Development, Urban Renewal Administration. 1965. Urban Renewal Project Characteristics, December 31, 1965. Washington, DC: HUD.

Federal Bureau of Investigation. 1961. Uniform Crime Reports, 1960. Washington, DC: Government Printing Office.

Galster, George C. 1990. "White Flight from Racially Integrated Neighbourhoods in the 1970s: the 
Cleveland Experience." Urban Studies 27: 385-399.

Glaeser, Edward L., Jose A. Scheinkman, and Andrei Sheifer. 1995. "Economic Growth in a CrossSection of Cities." Journal of Monetary Economics 36: 117-144.

Glaeser, Edward L. and Joseph Gyourko. 2005. Urban Decline and Durable Housing. Journal of Political Economy 113: 345-375.

Harrell, Adele, and Caterina Gouvis. 1995. Anticipating and Combating Community Decay and Crime in Washington, DC, and Cleveland, Ohio, 1980-1990. [Computer file]. ICPSR version. Washington, DC: The Urban Institute [producer]. Ann Arbor, MI: Inter-University Consortium for Political and Social Research [distributor].

Henderson, William D. 2002. "Demography and Desegregation in the Cleveland Public Schools: Toward a Comprehensive Theory of Educational Failure and Success." New York University Review of Law \& Social Change 26: 457-568.

Kelly, William R. and David Snyder. 1980. "Racial Violence and Socioeconomic Changes among Blacks in the United States." Social Forces 58: 739-760.

Kennedy, Peter E. 1981. "Estimation with Correctly Interpreted Dummy Variables in Semilogarithmic Equations." American Economic Review 71: 801.

Kusmer, Kenneth L. 1976. A Ghetto Takes Shape: Black Cleveland, 1870-1930. Urbana: University of Illinois Press.

Lackritz, Marc E. 1968. The Hough Riots of 1966. Cleveland, Ohio: Regional Church Planning Office, Report Number Forty-Three. (Originally submitted as thesis at the Woodrow Wilson School of Public and International Affairs, Princeton University).

Massey, Douglas S. and Nancy A. Denton. 1993. American Apartheid: Segregation and the Making of the Underclass. Cambridge, MA: Harvard University Press.

McWhorter, John. 2005. "Burned, Baby, Burned: Watts and the Tragedy of Black America." Washington Post, August 14: B1.

Miller, Carol Poh and Robert A. Wheeler. 1997. Cleveland: A Concise History, 1796-1996. Bloomington, Indiana: Indiana University Press.

Mills, Edwin. 1972. Studies in the Structure of the Urban Economy. Baltimore: Johns Hopkins Press.

Muth, R. 1969. Cities and Housing. Chicago, Illinois: The University of Chicago Press.

Myers, Daniel J. 1997. "Racial Rioting in the 1960s: An Event History Analysis of Local Conditions," American Sociological Review 64: 94-112.

Rosenbaum, P. and D. B. Rubin. 1983. "The Central Role of Propensity Score in Observational Studies for Causal Effects.” Biometrika 70: 41-55. 
Smith, Fred H. 2003. "Historical Evidence on the Monocentric Urban Model: A Case Study of Cleveland, 1915 - 1980," Applied Economics Letters 10: 729-731

Spilerman, Seymour. 1970. "The Causes of Racial Disturbances: A Comparison of Alternative Explanations," American Sociological Review 35: 627-649.

Spilerman, Seymour. 1971. "The Causes of Racial Disturbances: Test of an Explanation," American Sociological Review 36: 427-442.

Spilerman, Seymour. 1976. "Structural Characteristics of Cities and the Severity of Racial Disorders," American Sociological Review 41: 771-793.

Wanderer, Jules J. 1969. “An Index of Riot Severity and Some Correlates.” American Journal of Sociology 74: 500-505.

Welch, Finis and Audrey Light. 1987. New Evidence on School Desegregation. Washington, DC: U.S. Commission on Civil Rights, Clearning House Publication 92. (Data CD distributed by Unicon Research Corporation, 2004.)

Wilkins, Roger. 2005. “The Watts Riot, Burned into Memory.” Washington Post, August 23: A15.

Wilson, William Julius. 1987. The Truly Disadvantaged: The Inner City, the Underclass, and Public Policy. Chicago: University of Chicago Press. 
Table 1: Riots in Cleveland and the United States, 1964-1971

\begin{tabular}{llllll}
\hline & Hough Riot & $\begin{array}{l}\text { Glenville } \\
\text { Shootout }\end{array}$ & $\begin{array}{l}\text { All Cleveland } \\
\text { Riots }\end{array}$ & $\begin{array}{l}\text { Median for Other Average for } \\
\text { Large Cities }\end{array}$ & $\begin{array}{l}\text { Other Large } \\
\text { Cities }\end{array}$ \\
\hline Days & 5 & 4 & 14 & 16 & 16.75 \\
Deaths & 4 & 10 & 14 & 1 & 6.45 \\
Injuries & 60 & 27 & 100 & 102 & 311 \\
Arsons & 531 & 24 & 556 & 192 & 483 \\
Arrests & 3253 & 96 & 3364 & 647 & 1974 \\
Index & 0.106 & 0.051 & 0.161 & 0.069 & 0.121 \\
\hline
\end{tabular}

Notes: "Other large cities" includes cities with populations of at least 500,000 in 1960.

Source: The data underlie Carter (1986). 
Table 2: Riots and Tract Property Values, 1960 to 1980, OLS Estimates

\begin{tabular}{llllll}
\hline \multicolumn{1}{l}{} & 1 & 2 & 3 & 4 & 5 \\
\hline Panel A: Hough "Riot Tracts" & & & & & \\
Riot Tract & & & & & \\
& -0.391 & -0.404 & -0.349 & -0.342 & -0.197 \\
Pre-1960 Value Trend & $(0.0456)$ & $(0.0303)$ & $(0.0308)$ & $(0.0324)$ & $(0.0399)$ \\
& ---- & --- & -0.680 & -0.504 & -0.216 \\
Prop. Dilapidated 1960 & ---- & ---- & $(0.249)$ & $(0.235)$ & $(0.230)$ \\
& & --- & -1.549 & -1.450 \\
1960 Black Proportion & ---- & ---- & --- & $(0.334)$ & $(0.250)$ \\
& & & --- & -0.292 \\
Constant & 0.582 & 0.631 & 0.857 & 0.786 & $0.0368)$ \\
N & $(0.0192)$ & $(0.183)$ & $(0.0857)$ & $(0.0760)$ & $(0.0805)$ \\
R-squared & 180 & 151 & 151 & 151 & 151 \\
\hline
\end{tabular}

Panel B: Hough and Glenville "Riot Tracts"

\begin{tabular}{llllll} 
Riot Tract & -0.293 & -0.328 & -0.321 & -0.332 & -0.223 \\
& $(0.0363)$ & $(0.0309)$ & $(0.0303)$ & $(0.0282)$ & $(0.0407)$ \\
Pre-1960 Value Trend & --- & --- & -0.795 & -0.596 & -0.391 \\
& & & $(0.209)$ & $(0.189)$ & $(0.189)$ \\
Prop. Dilapidated 1960 & ---- & ---- & --- & -1.718 & -1.602 \\
& & & & $(0.339)$ & $(0.284)$ \\
1960 Black Proportion & ---- & --- & --- & --- & -0.186 \\
& & & & & $(0.045)$ \\
Constant & 0.599 & 0.657 & 0.925 & 0.898 & 0.848 \\
& $(0.0202)$ & $(0.0186)$ & $(0.0696)$ & $(0.0625)$ & $(0.0624)$ \\
N & 180 & 151 & 151 & 151 & 151 \\
R-squared & 0.15 & 0.25 & 0.36 & 0.47 & 0.51 \\
\hline
\end{tabular}

Notes: The dependent variable is the change in log median property value for owner-occupied single family housing units. The "riot tract" variable is a dummy variable that is narrowly defined in panel A (including only the tracts directly affected by the Hough Riot) and broadly defined in panel B (including the entire area cordoned off during the Glenville Shootout).

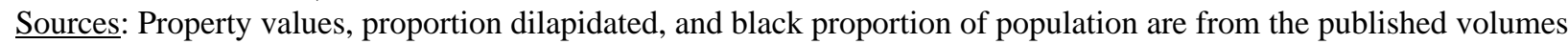
of the censuses of housing and population from 1950 to 1980. 
Table 3: Riots and Tract Property Values, 1960 to 1980, Matching Estimates

\begin{tabular}{|c|c|c|c|c|c|c|}
\hline & 1 & 2 & 3 & 4 & 5 & 6 \\
\hline \multicolumn{7}{|c|}{ Panel A: Hough "Riot Tracts" } \\
\hline $\begin{array}{l}\text { Avg. Treatment } \\
\text { Effect }\end{array}$ & $\begin{array}{l}-0.202 \\
(0.079)\end{array}$ & $\begin{array}{l}-0.304 \\
(0.105)\end{array}$ & $\begin{array}{l}-0.173 \\
(0.066)\end{array}$ & $\begin{array}{l}-0.295 \\
(0.066)\end{array}$ & $\begin{array}{l}-0.284 \\
(0.076)\end{array}$ & $\begin{array}{l}-0.216 \\
(0.064)\end{array}$ \\
\hline Treated Group & 10 & 10 & 8 & 10 & 10 & 8 \\
\hline Control group & 15 & 8 & 7 & 170 & 170 & 143 \\
\hline Common support & Y & $\mathrm{Y}$ & Y & $\mathrm{N}$ & $\mathrm{N}$ & $\mathrm{N}$ \\
\hline Matched using & Pblk60 & $\begin{array}{l}\text { Pblk60 and } \\
\Delta \text { Pblk5060 }\end{array}$ & $\begin{array}{l}\text { Pblk60, } \\
\Delta \text { Pblk5060, } \\
\Delta \text { Val5060 }\end{array}$ & Pblk60 & $\begin{array}{l}\text { Pblk60 and } \\
\Delta \text { Pblk5060 }\end{array}$ & $\begin{array}{l}\text { Pblk60, } \\
\Delta \text { Pblk5060, } \\
\Delta \text { Val5060 }\end{array}$ \\
\hline \multicolumn{7}{|c|}{ Panel B: Hough and Glenville "Riot Tracts" } \\
\hline $\begin{array}{l}\text { Avg. Treatment } \\
\text { Effect }\end{array}$ & $\begin{array}{l}-0.116 \\
(0.067)\end{array}$ & $\begin{array}{l}-0.219 \\
(0.081)\end{array}$ & $\begin{array}{l}-0.254 \\
(0.067)\end{array}$ & $\begin{array}{l}-0.122 \\
(0.057)\end{array}$ & $\begin{array}{l}-0.242 \\
(0.095)\end{array}$ & $\begin{array}{l}-0.250 \\
(0.073)\end{array}$ \\
\hline Treated Group & 24 & 24 & 22 & 24 & 24 & 22 \\
\hline Control Group & 77 & 63 & 51 & 156 & 156 & 129 \\
\hline Common support & $\mathrm{Y}$ & $\mathrm{Y}$ & $\mathrm{Y}$ & $\mathrm{N}$ & $\mathrm{N}$ & $\mathrm{N}$ \\
\hline Matched using & Pblk60 & $\begin{array}{l}\text { Pblk60 and } \\
\Delta \text { Pblk5060 }\end{array}$ & $\begin{array}{l}\text { Pblk60, } \\
\Delta \text { Pblk5060, } \\
\Delta \text { Val5060 }\end{array}$ & Pblk60 & $\begin{array}{l}\text { Pblk60 and } \\
\Delta \text { Pblk5060 }\end{array}$ & $\begin{array}{l}\text { Pblk60, } \\
\Delta \text { Pblk5060, } \\
\Delta \text { Val5060 }\end{array}$ \\
\hline
\end{tabular}

Notes: The kernel matching approach weights non-treated tracts for comparison with each treated tract. Each nontreated tract's weight is inversely related to its propensity score's distance from that of the treated tract. In columns 1 and 4, propensity scores are estimated on the basis of the black proportion of the population in 1960. In columns 2 and 5, propensity scores are based on black proportion in 1960 and the change in the black proportion from 1950 to 1960. In columns 3 and 6, propensity scores are additionally based on the pre-1960 trend in median property value (due to missing data for 1950, some tracts are lost from the sample). Standard errors for the estimates are bootstrapped. Estimates in columns 1 to 3 restrict comparisons to tracts with "common support" and columns 4 to 6 do not (see Becker and Ichino (2002) for a discussion of the issue). Estimates are roughly similar in magnitude and statistical significance if the matching also accounts for median property value in 1960 and proportion of units dilapidated in 1960, but in these cases the "balancing property" is not always satisfied (that is, within one of the comparison sub-groups the mean value of proportion dilapidated or median house value differs between treatment and control tracts). Estimates in panel A allow tracts affected by the Glenville riot to serve in the control group, and this may tend to bias the riot effect estimate downward. Excluding the tracts directed affected by the Glenville Shootout (but not by the Hough riot) tends to raise the estimated Hough riot effect. Sources: We compiled the census tract data from the published volumes of the 1950, 1960 and 1980 federal census of housing. 
Table 4: Distance-from-Riot and Tract Property Values, 1960-1980, OLS Estimates

\begin{tabular}{|c|c|c|c|c|c|}
\hline & 1 & 2 & 3 & 4 & 5 \\
\hline Distance & $\begin{array}{l}0.153 \\
(0.0115)\end{array}$ & $\begin{array}{l}0.141 \\
(0.00903)\end{array}$ & $\begin{array}{l}0.138 \\
(0.00937)\end{array}$ & $\begin{array}{l}0.135 \\
(0.00923)\end{array}$ & $\begin{array}{l}0.133 \\
(0.0107)\end{array}$ \\
\hline Distance $^{2}$ & $\begin{array}{l}-0.00678 \\
(0.000940)\end{array}$ & $\begin{array}{l}-0.00603 \\
(0.000767)\end{array}$ & $\begin{array}{l}-0.00599 \\
(0.000791)\end{array}$ & $\begin{array}{l}-0.00595 \\
(0.000783)\end{array}$ & $\begin{array}{l}-0.00583 \\
(0.000841)\end{array}$ \\
\hline Pre-1960 Value Trend & ---- & ---- & $\begin{array}{l}-0.365 \\
(0.122)\end{array}$ & $\begin{array}{l}-0.308 \\
(0.119)\end{array}$ & $\begin{array}{l}-0.300 \\
(0.120)\end{array}$ \\
\hline Prop. Dilapidated 1960 & ---- & ---- & ---- & $\begin{array}{l}-0.639 \\
(0.192)\end{array}$ & $\begin{array}{l}-0.644 \\
(0.191)\end{array}$ \\
\hline 1960 Black Proportion & ---- & ---- & ---- & ---- & $\begin{array}{l}-0.00862 \\
(0.0253)\end{array}$ \\
\hline Constant & $\begin{array}{l}0.0899 \\
(0.0310)\end{array}$ & $\begin{array}{l}0.129 \\
(0.0225)\end{array}$ & $\begin{array}{l}0.268 \\
(0.0569)\end{array}$ & $\begin{array}{l}0.276 \\
(0.0556)\end{array}$ & $\begin{array}{l}0.280 \\
(0.0588)\end{array}$ \\
\hline $\mathrm{N}$ & 180 & 151 & 151 & 151 & 151 \\
\hline R-squared & 0.75 & 0.80 & 0.82 & 0.84 & 0.84 \\
\hline Mean Dependent Var. & 0.560 & 0.609 & 0.609 & 0.609 & 0.609 \\
\hline Mean Distance & 4.12 & 4.56 & 4.56 & 4.56 & 4.56 \\
\hline
\end{tabular}

Notes: Distance from the corner of Hough Avenue and East $79^{\text {th }}$ Street is calculated using the longitude and latitude coordinates of the centroid of each census tract.

Sources: Property values, proportion dilapidated, and black proportion of population are from the published volumes of the censuses of housing and population from 1950 to 1980. 
Table 5: Riots and Tract Property Values, Controlling for Crime, 1960-1980

\begin{tabular}{|c|c|c|c|c|c|c|}
\hline & 1 & 2 & 3 & 4 & 5 & 6 \\
\hline Riot Tract (Hough riot) & $\begin{array}{l}-0.344 \\
(0.0482)\end{array}$ & $\begin{array}{l}-0.398 \\
(0.0348)\end{array}$ & --- & --- & --- & --- \\
\hline $\begin{array}{l}\text { Riot Tract (Hough and } \\
\text { Glenville riot) }\end{array}$ & --- & --- & $\begin{array}{l}-0.262 \\
(0.0351)\end{array}$ & $\begin{array}{l}-0.334 \\
(0.0310)\end{array}$ & --- & --- \\
\hline Distance & --- & --- & --- & --- & $\begin{array}{l}0.144 \\
(0.0104)\end{array}$ & $\begin{array}{l}0.142 \\
(0.00976)\end{array}$ \\
\hline Distance $^{2}$ & --- & --- & --- & --- & $\begin{array}{l}-0.00636 \\
(0.000873)\end{array}$ & $\begin{array}{l}-0.00656 \\
(0.000852)\end{array}$ \\
\hline Homicide Rate in 1980 & $\begin{array}{l}-0.153 \\
(0.0233)\end{array}$ & --- & $\begin{array}{l}-0.151 \\
(0.0231)\end{array}$ & --- & $\begin{array}{l}-0.0412 \\
(0.0147)\end{array}$ & --- \\
\hline Burglary Rate in 1980 & --- & $\begin{array}{l}-0.00664 \\
(0.000961)\end{array}$ & --- & $\begin{array}{l}-0.00713 \\
(0.000973)\end{array}$ & --- & $\begin{array}{l}-0.00272 \\
(0.000682)\end{array}$ \\
\hline Constant & $\begin{array}{l}0.664 \\
(0.0218)\end{array}$ & $\begin{array}{l}0.813 \\
(0.0372)\end{array}$ & $\begin{array}{l}0.679 \\
(0.0222)\end{array}$ & $\begin{array}{l}0.852 \\
(0.0374)\end{array}$ & $\begin{array}{l}0.141 \\
(0.0290)\end{array}$ & $\begin{array}{l}0.223 \\
(0.0317)\end{array}$ \\
\hline $\mathrm{N}$ & 179 & 179 & 179 & 179 & 179 & 179 \\
\hline R-squared & 0.29 & 0.38 & 0.32 & 0.44 & 0.76 & 0.79 \\
\hline Mean Dependent Var. & 0.563 & 0.563 & 0.563 & 0.563 & 0.563 & 0.563 \\
\hline Mean Homicide Rate & 0.538 & --- & 0.538 & --- & 0.538 & --- \\
\hline Mean Burglary Rate & --- & 13.7 & --- & 13.7 & --- & 13.7 \\
\hline
\end{tabular}

Notes: The dependent variable is the change in log median property value of owner-occupied housing in each tract. Some tracts in central business district do not have housing values reported and are omitted from the regressions. The "riot tract" variable is a dummy variable that is narrowly defined in columns 1 and 4 (set equal to 1 only for tracts directly affected by the Hough Riot in 1966) and broadly defined in columns 2 and 5 (set equal to 1 for the entire area cordoned off during the Glenville Shootout, which includes the Hough riot area). Distance from the corner of Hough Avenue and East $79^{\text {th }}$ Street is calculated using the longitude and latitude coordinates of the centroid of each census tract.

Sources: Property value data are from the published census volumes. Crime rates are per 1,000 population, from ICPSR Study 6486 (Harrell and Gouvis 1995). 
Table 6: Riots and Property Value Changes,

Controlling for Changes in Housing Stock Characteristics, 1960-1980

\begin{tabular}{llllllllll}
\hline & 1 & 2 & 3 & 4 & 5 & 6 & 7 & 8 & 9 \\
\hline Riot Tract (Hough riot) & -0.442 & -0.317 & -0.152 & --- & --- & --- & --- & --- & --- \\
& $(0.055)$ & $(0.075)$ & $(0.069)$ & & & & & & \\
Riot Tract (Hough and & --- & --- & --- & -0.295 & -0.229 & -0.174 & --- & --- & --- \\
Glenville riot) & & & & $(0.039)$ & $(0.045)$ & $(0.034)$ & & & \\
Distance & --- & --- & --- & --- & --- & --- & 0.157 & 0.152 & 0.127 \\
& & & & & & & $(0.011)$ & $(0.012)$ & $(0.012)$ \\
Distance & --- & --- & --- & --- & --- & --- & -0.007 & -0.007 & -0.006 \\
& & & & & & & $(0.001)$ & $(0.001)$ & $(0.001)$ \\
Proportion built 1960-80 & 0.412 & 0.0375 & 0.004 & 0.226 & -0.090 & -0.018 & 0.182 & 0.169 & 0.147 \\
& $(0.170)$ & $(0.226)$ & $(0.133)$ & $(0.166)$ & $(0.205)$ & $(0.128)$ & $(0.117)$ & $(0.114)$ & $(0.116)$ \\
Change in prop. owner & --- & -0.180 & -0.005 & --- & -0.064 & 0.167 & -- & 0.750 & 0.696 \\
occ. & & $(0.349)$ & $(0.277)$ & & $(0.353)$ & $(0.283)$ & & $(0.251)$ & $(0.222)$ \\
Change in median rooms & --- & -0.264 & -0.020 & --- & -0.287 & -0.023 & --- & -0.179 & -0.086 \\
& & $(0.093)$ & $(0.067)$ & & $(0.088)$ & $(0.066)$ & & $(0.044)$ & $(0.043)$ \\
Change in num. units & --- & --- & 0.471 & --- & --- & 0.471 & --- & --- & 0.200 \\
& & & $(0.071)$ & & & $(0.071)$ & & & $(0.037)$ \\
Constant & 0.546 & 0.607 & 0.698 & 0.578 & 0.638 & 0.698 & 0.067 & 0.121 & 0.229 \\
& $(0.023)$ & $(0.030)$ & $(0.023)$ & $(0.025)$ & $(0.030)$ & $(0.023)$ & $(0.030)$ & $(0.031)$ & $(0.034)$ \\
N & 180 & 180 & 180 & 180 & 180 & 180 & 180 & 180 & 180 \\
R-squared & 0.15 & 0.24 & 0.55 & 0.16 & 0.25 & 0.55 & 0.76 & 0.79 & 0.83 \\
Mean Dependent Var. & 0.560 & 0.560 & 0.560 & 0.560 & 0.560 & 0.560 & 0.560 & 0.560 & 0.560 \\
Mean Prop built 1960-80 & 0.093 & 0.093 & 0.093 & 0.093 & 0.093 & 0.093 & 0.093 & 0.093 & 0.093 \\
Mean Chg in prop. own. & --- & -0.028 & -0.028 & --- & -0.028 & -0.028 & --- & -0.028 & -0.028 \\
Mean Chg in med. rooms & --- & 0.143 & 0.143 & --- & 0.143 & 0.143 & --- & 0.143 & 0.143 \\
Mean Chg in num. units & --- & --- & -0.224 & --- & --- & -0.224 & --- & --- & -0.224 \\
\hline N
\end{tabular}

Notes: The change in the proportion of housing units that are owner-occupied and the change in the median number of rooms per unit are simple differences (1980 minus 1960 value). The change in the number of housing using is the $\log$ change $(\ln (1980$ units/1960 units)). See notes in earlier tables for a description of the Hough, Glenville, and distance measures of riot proximity.

Sources: Property values and housing stock characteristics are from the published volumes of the census. 
Table 7: Riots and Population Change, 1960-1980

\begin{tabular}{|c|c|c|c|c|c|c|c|c|c|}
\hline & 1 & 2 & 3 & 4 & 5 & 6 & 7 & 8 & 9 \\
\hline Riot Tract (Hough riot) & $\begin{array}{l}-0.624 \\
(0.106)\end{array}$ & $\begin{array}{l}-0.345 \\
(0.115)\end{array}$ & $\begin{array}{l}-0.420 \\
(0.101)\end{array}$ & --- & --- & --- & --- & --- & --- \\
\hline $\begin{array}{l}\text { Riot Tract (Hough and } \\
\text { Glenville riot) }\end{array}$ & --- & --- & --- & $\begin{array}{l}-0.281 \\
(0.087)\end{array}$ & $\begin{array}{c}0.047 \\
(0.108)\end{array}$ & $\begin{array}{l}-0.063 \\
(0.090)\end{array}$ & --- & --- & --- \\
\hline Distance & --- & --- & --- & --- & --- & --- & $\begin{array}{c}0.245 \\
(0.029)\end{array}$ & $\begin{array}{c}0.180 \\
(0.039)\end{array}$ & $\begin{array}{r}0.204 \\
(0.033)\end{array}$ \\
\hline Distance $^{2}$ & --- & --- & --- & --- & --- & --- & $\begin{array}{l}-0.016 \\
(0.003)\end{array}$ & $\begin{array}{l}-0.012 \\
(0.003)\end{array}$ & $\begin{array}{l}-0.012 \\
(0.003)\end{array}$ \\
\hline Pop. Change 1950-60 & $\begin{array}{c}0.553 \\
(0.207)\end{array}$ & $\begin{array}{c}0.500 \\
(0.194)\end{array}$ & $\begin{array}{c}0.243 \\
(0.178)\end{array}$ & $\begin{array}{c}0.547 \\
(0.206)\end{array}$ & $\begin{array}{c}0.467 \\
(0.192)\end{array}$ & $\begin{array}{c}0.218 \\
(0.179)\end{array}$ & $\begin{array}{c}0.339 \\
(0.228)\end{array}$ & $\begin{array}{c}0.377 \\
(0.236)\end{array}$ & $\begin{array}{l}0.019 \\
(0.19)\end{array}$ \\
\hline Black Proportion 1960 & --- & $\begin{array}{l}-0.527 \\
(0.116)\end{array}$ & $\begin{array}{l}-0.345 \\
(0.082)\end{array}$ & --- & $\begin{array}{l}-0.610 \\
(0.135)\end{array}$ & $\begin{array}{l}-0.398 \\
(0.099)\end{array}$ & --- & $\begin{array}{l}-0.302 \\
(0.160)\end{array}$ & $\begin{array}{l}-0.060 \\
(0.086)\end{array}$ \\
\hline Homicide Rate 1980 & --- & --- & $\begin{array}{l}-0.078 \\
(0.044)\end{array}$ & --- & --- & $\begin{array}{l}-0.081 \\
(0.045)\end{array}$ & --- & --- & $\begin{array}{l}-0.038 \\
(0.037)\end{array}$ \\
\hline Constant & $\begin{array}{l}-0.470 \\
(0.029)\end{array}$ & $\begin{array}{l}-0.357 \\
(0.032)\end{array}$ & $\begin{array}{l}-0.329 \\
(0.036)\end{array}$ & $\begin{array}{l}-0.468 \\
(0.031)\end{array}$ & $\begin{array}{l}-0.361 \\
(0.031)\end{array}$ & $\begin{array}{l}-0.329 \\
(0.036)\end{array}$ & $\begin{array}{l}-1.131 \\
(0.078)\end{array}$ & $\begin{array}{l}-0.883 \\
(0.143)\end{array}$ & $\begin{array}{l}-0.992 \\
(0.105)\end{array}$ \\
\hline $\mathrm{N}$ & 200 & 200 & 193 & 200 & 200 & 193 & 200 & 200 & 193 \\
\hline R-squared & 0.17 & 0.29 & 0.25 & 0.14 & 0.27 & 0.21 & 0.31 & 0.33 & 0.34 \\
\hline Mean Dependent Var. & -0.541 & -0.541 & -0.489 & -0.541 & -0.541 & -0.489 & -0.541 & -0.541 & -0.489 \\
\hline
\end{tabular}

Notes: The dependent variable is the change in log population in each tract. Robust standard errors are in parentheses. Tracts with zero population in any year are omitted from the regressions. Distance from the corner of Hough Avenue and East $79^{\text {th }}$ Street is calculated using the longitude and latitude coordinates of the centroid of each census tract.

Sources: Property value data are from the published census volumes. The homicide rate (per 1,000 population) is calculated using ICPSR Study 6486 (Harrell and Gouvis 1995). 
Appendix Table 1: Riots and Property Values, 1960-1980

\begin{tabular}{rrrr}
\hline & 1 & 2 & 3 \\
\hline Distance & 0.122 & 0.116 & 0.125 \\
& $(0.013)$ & $(0.0125)$ & $(0.0115)$ \\
Distance2 & -0.00535 & -0.00498 & -0.00586 \\
& $(0.000954)$ & $(0.000945)$ & $(0.000901)$ \\
Prop built 1960-80 & 0.162 & 0.108 & 0.221 \\
& $(0.120)$ & $(0.103)$ & $(0.102)$ \\
Chg in prop own occ & 0.641 & 0.420 & 0.481 \\
& $(0.245)$ & $(0.208)$ & $(0.188)$ \\
Chg in median room & -0.0784 & -0.0204 & -0.0154 \\
& $(0.0426)$ & $(0.0415)$ & $(0.0389)$ \\
Chg in num. units & 0.174 & 0.154 & 0.130 \\
& $(0.0411)$ & $(0.0354)$ & $(0.0358)$ \\
Homicide 1980 & -0.0101 & -0.0154 & -0.0253 \\
& $(0.014)$ & $(0.0160)$ & $(0.0158)$ \\
Burglary 1980 & -0.000813 & -0.000443 & -0.000311 \\
& $(0.000780)$ & $(0.000720)$ & $(0.000683)$ \\
Prop black 1960 & -0.0248 & -0.0579 & -0.0291 \\
& $(0.0300)$ & $(0.0263)$ & $(0.0233)$ \\
Prop dilap. 1960 & 0.0628 & -0.278 & -0.200 \\
& $(0.302)$ & $(0.157)$ & $(0.146)$ \\
Constant & 0.272 & 0.285 & 0.354 \\
& $(0.0435)$ & $(0.0422)$ & $(0.0562)$ \\
Chg. in value 1950-60 & --- & -0.322 \\
& & & $(0.114)$ \\
R-squared & 179 & 151 & 151 \\
\hline
\end{tabular}

Notes: The dependent variable is change in log median value of owner occupied housing. Regressions are estimated using ordinary least squares. Robust standard errors are in parentheses. Distance is calculated from the center of each tract to the corner of Hough Avenue and East $79^{\text {th }}$ Street, as described in text.

Sources: Property value data, proportion black, and housing stock information are from the published census volumes. Crime rates are per 1,000 population, from ICPSR Study 6486 (Harrell and Gouvis 1995). 
Appendix Table 2: Population Density, 1950-1980

\begin{tabular}{rrr}
\hline & 1960 & 1980 \\
\hline Distance & 1.796 & 0.846 \\
& $(0.525)$ & $(0.292)$ \\
Distance $^{2}$ & -0.465 & -0.002 \\
& $(1.085)$ & $(1.223)$ \\
Distance $^{3}$ & 0.017 & 0.002 \\
& $(0.007)$ & $(0.004)$ \\
East & 0.013 & -0.042 \\
East $^{2}$ & $(0.036)$ & $(0.037)$ \\
& 0.137 & -0.090 \\
East $^{3}$ & $(1.077)$ & $(1.225)$ \\
& 0.001 & 0.002 \\
North $^{*}$ & $(0.001)$ & $(0.001)$ \\
North $^{2}$ & 0.033 & -0.001 \\
& $(0.058)$ & $(0.062)$ \\
North $^{3}$ & 0.105 & -0.109 \\
& $(1.075)$ & $(1.224)$ \\
Constant & 0.000006 & 0.001 \\
& $(0.003)$ & $(0.003)$ \\
$\mathrm{N}$ & 5.973 & 6.323 \\
$\mathrm{~N}$ & $(0.772)$ & $(0.473)$ \\
& 198 & 195 \\
& 0.26 & 0.17 \\
\hline
\end{tabular}

Notes: These regressions underlie figures $6 \mathrm{~A}, 6 \mathrm{~B}$, and 7. The dependent variable is the natural log of population density. Population density is measured by census tract, and it is calculated as population per square kilometer. Distance is calculated from the center of each tract to the center of the city (Public Square) and direction is expressed (in miles) relative to the center of the city. Robust standard errors are in parentheses. Sources: Information on population, tract area, and tract longitude and latitude are available from the data documentation that accompanies Cutler, Glaeser, and Vigdor (1999), available at http://trinity.aas.duke.edu/ jvigdor/segregation/. 
Figure 1A: Population of Cleveland and Non-Cleveland Cuyahoga County

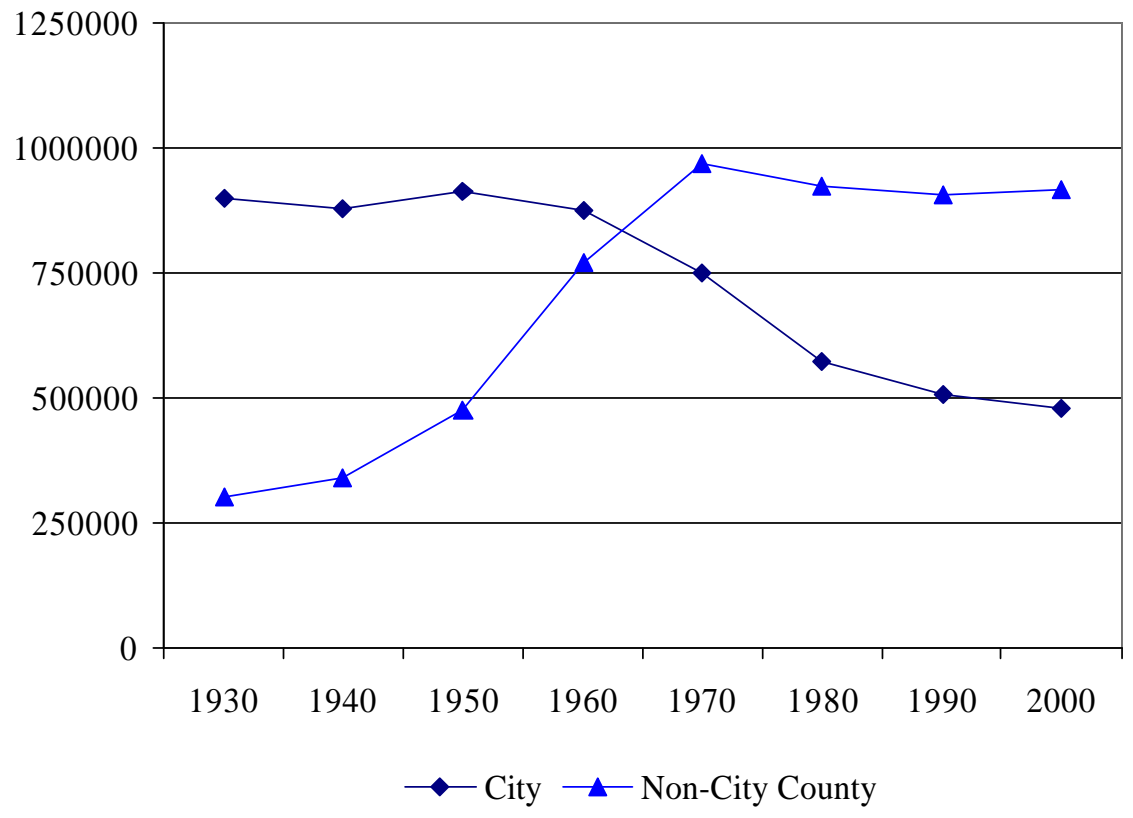

Figure 1B: Population Change in Cleveland and Non-Cleveland Cuyahoga County

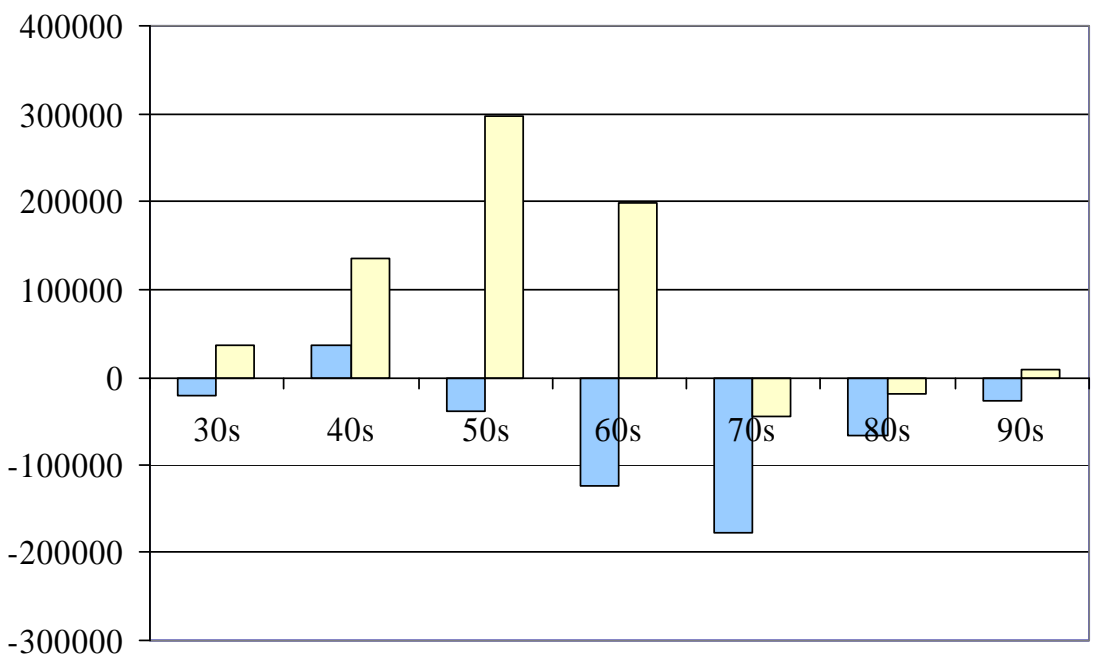

$\square$ City $\square$ Non-City County

Notes: Cleveland is located within Cuyahoga County, and so the sum of the "city" and "non-city" figures give the county's total population.

Sources: Population figures are from the federal Census of Population in each year. 
Figure 2: Census Tracts within the Hough and Glenville Riot Zones

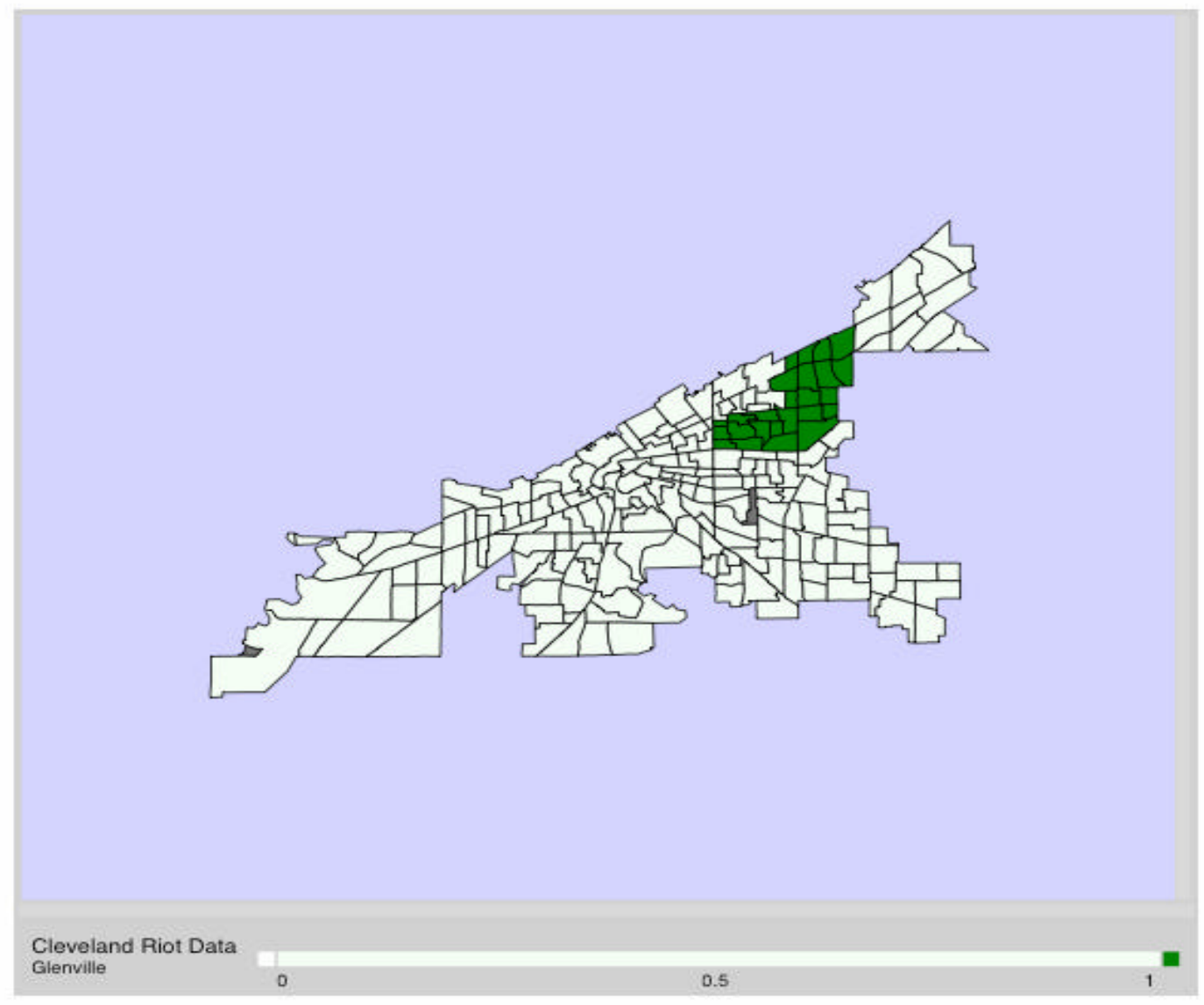


Figure 3A: Property Value Change and Distance from Riots, 1960 to 1980

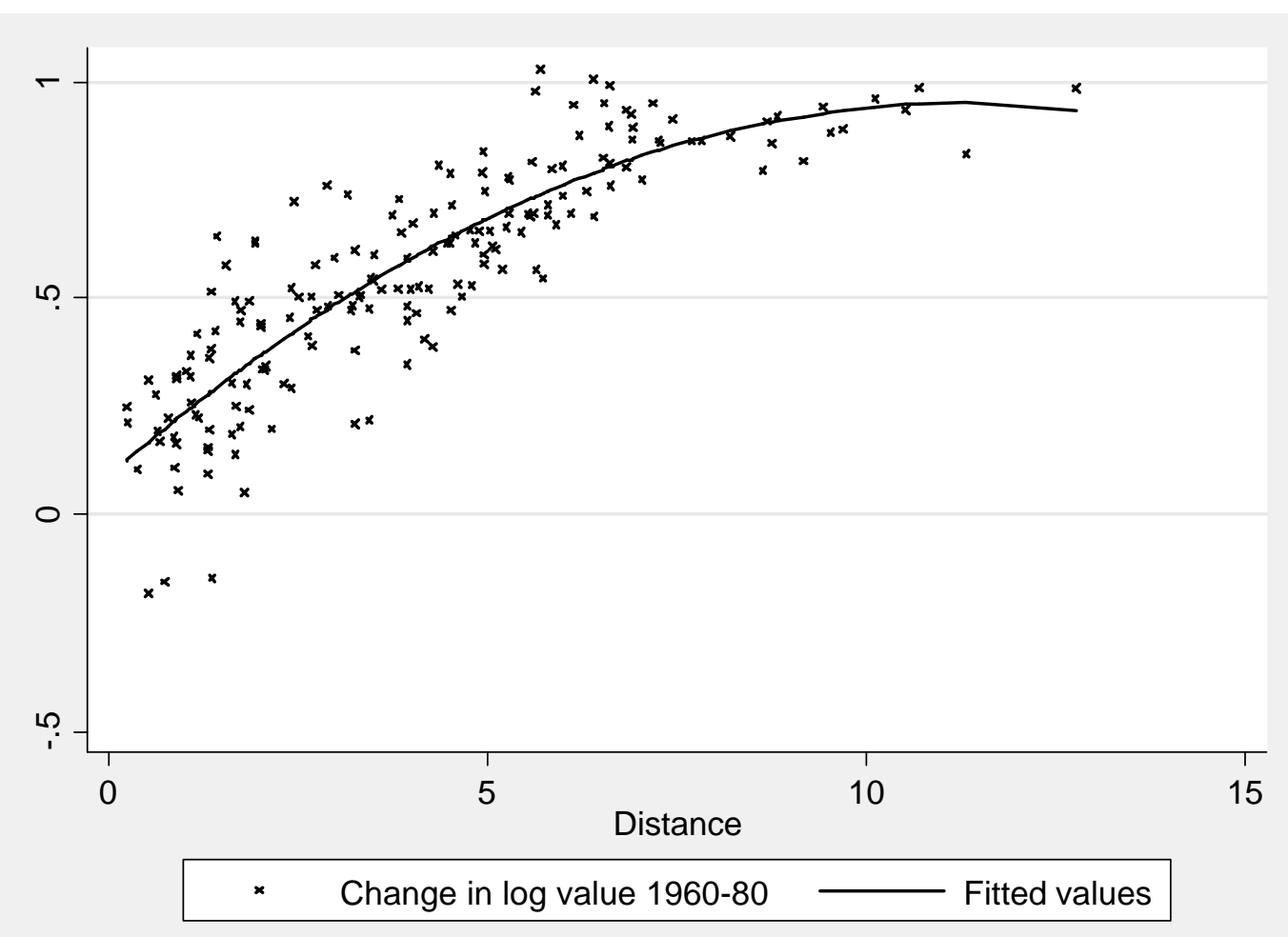

Figure 3B: Property Value Change and Distance from Riots, 1950 to 1960

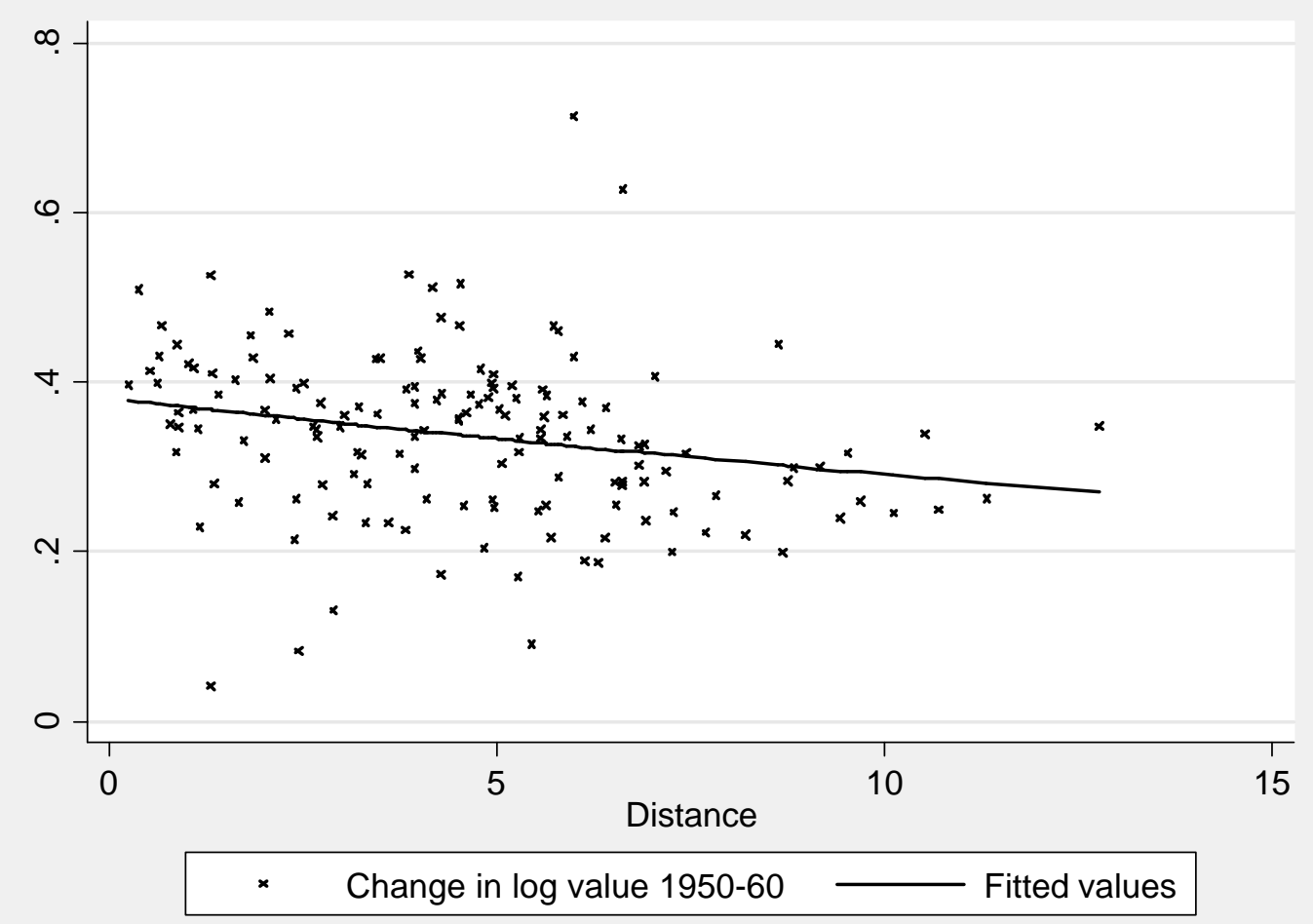


Notes: Each " $x$ " represents a census tract. Distance is straight-line distance from the center of the tract to the corner of Hough Avenue and East $79^{\text {th }}$ Street. Property value change is calculated as the log change in the median value of owner-occupied single-family housing.

Sources: Median property values are from the published volumes of the federal Census of Housing in 1950, 1960, and 1980. Latitude and longitude for tract centers are from the dataset associated with Cutler, Glaeser, and Vigdor (1999), available at: http://trinity.aas.duke.edu/ jvigdor/segregation/1990trct.txt. 
Figure 4A: Map of Residential Property Value Changes, 1960 to 1980

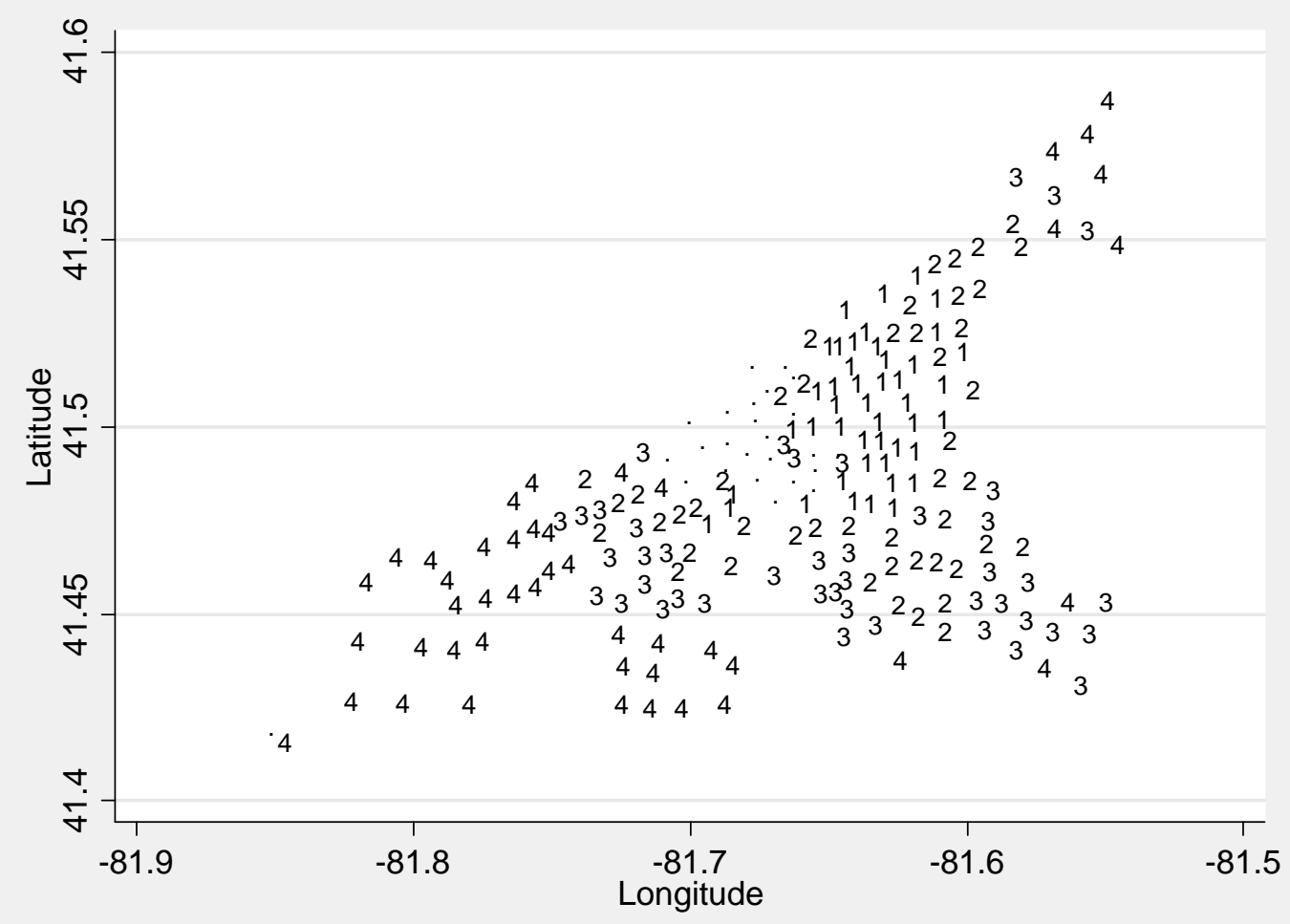

Figure 4B: Map of Residential Property Value Changes, 1950 to 1960

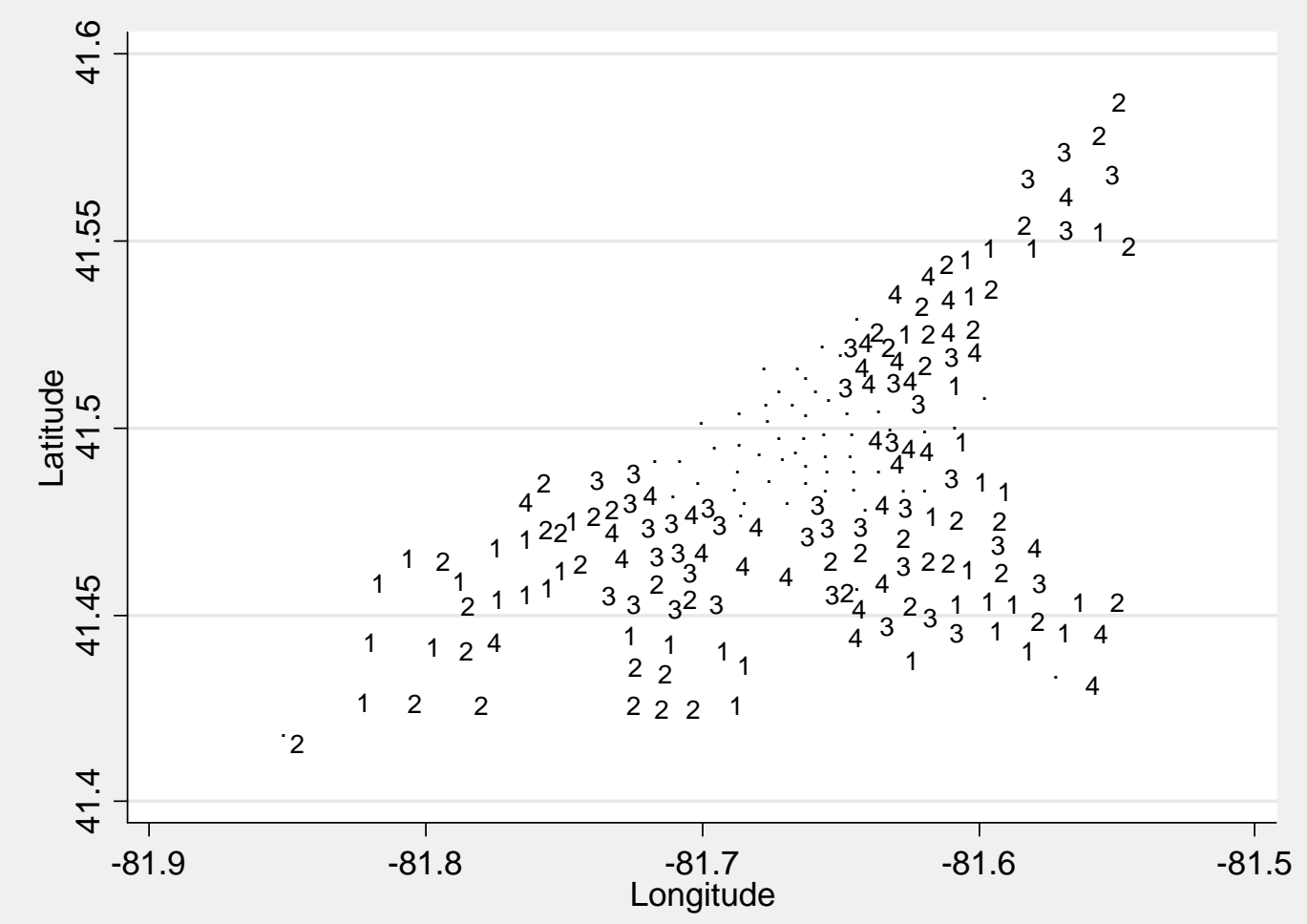


Notes: Each number is set at the center of a census tract, and therefore they trace out a map of Cleveland. Tracts with the lowest gains in median property value (in the first quartile) are labeled "1"; those with the largest gains in median property value (in the fourth quartile) are labeled " 4 ".

Sources: Median property values for owner-occupied, single-family housing are from the published volumes of the federal Census of Housing in 1950, 1960, and 1980. 
Figure 5A: Map of Population Changes, 1960 to 1980

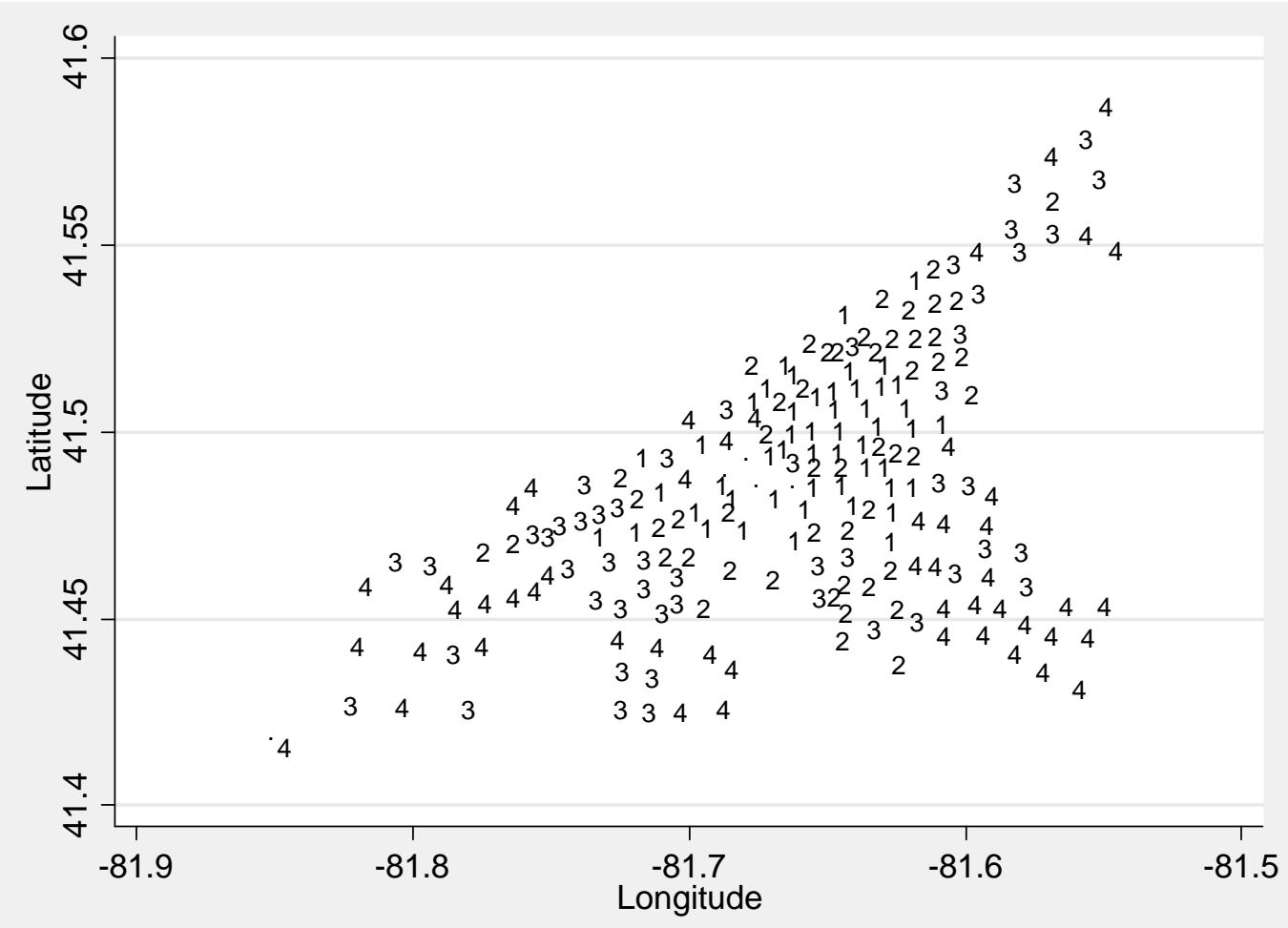

Figure 5B: Map of Population Changes, 1950 to 1960

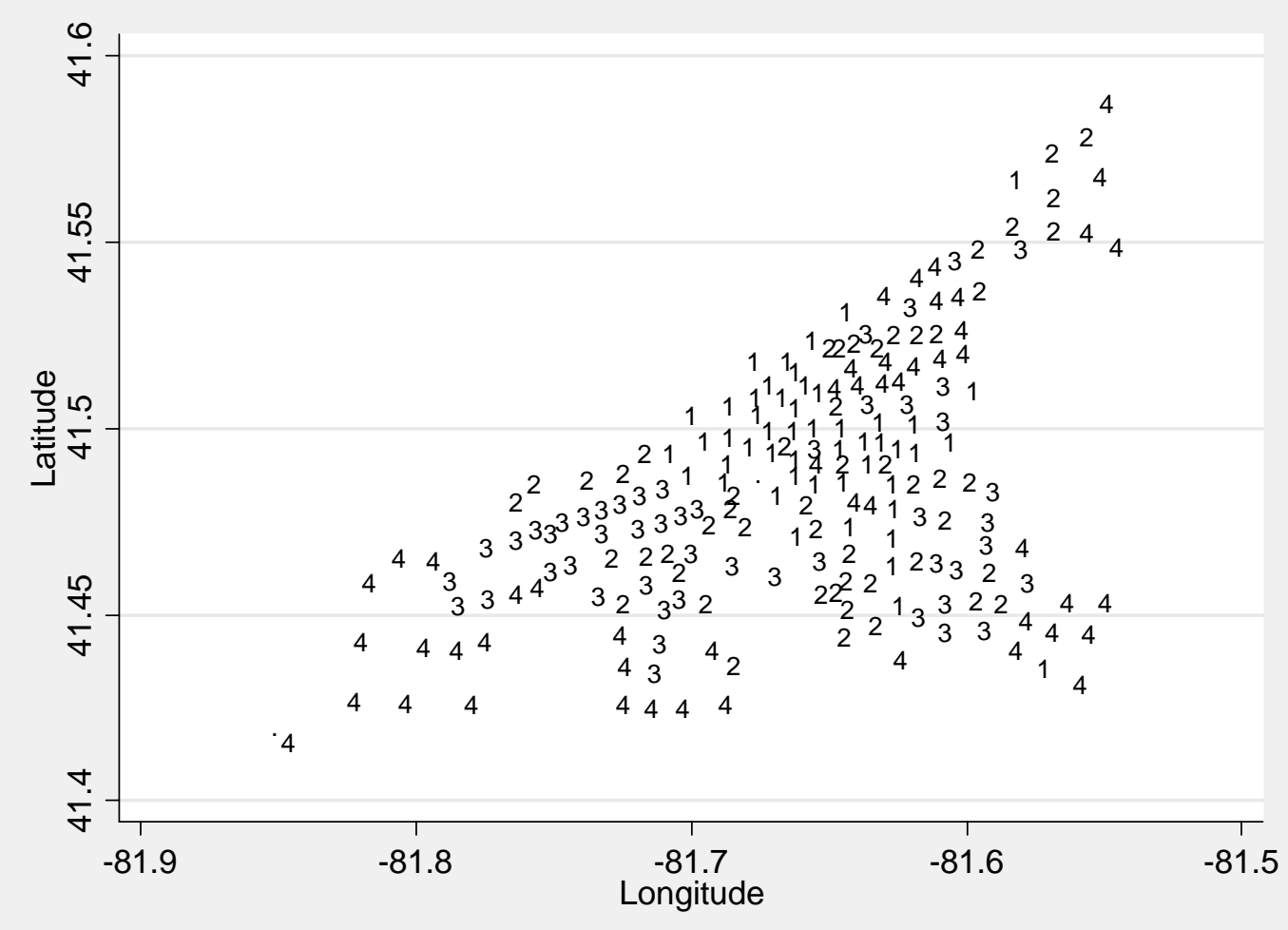


Notes: Each number is set at the center of a census tract, and therefore they trace out a map of Cleveland. Tracts with the lowest gains (biggest losses) in log population are labeled "1" (in the first quartile); those with the largest gains in log population (in the fourth quartile) are labeled "4".

Sources: Data are from the published volumes of the federal Census of Population in 1950, 1960, and 1980 
Figure 6A: Population Density, Viewed from South, 1960

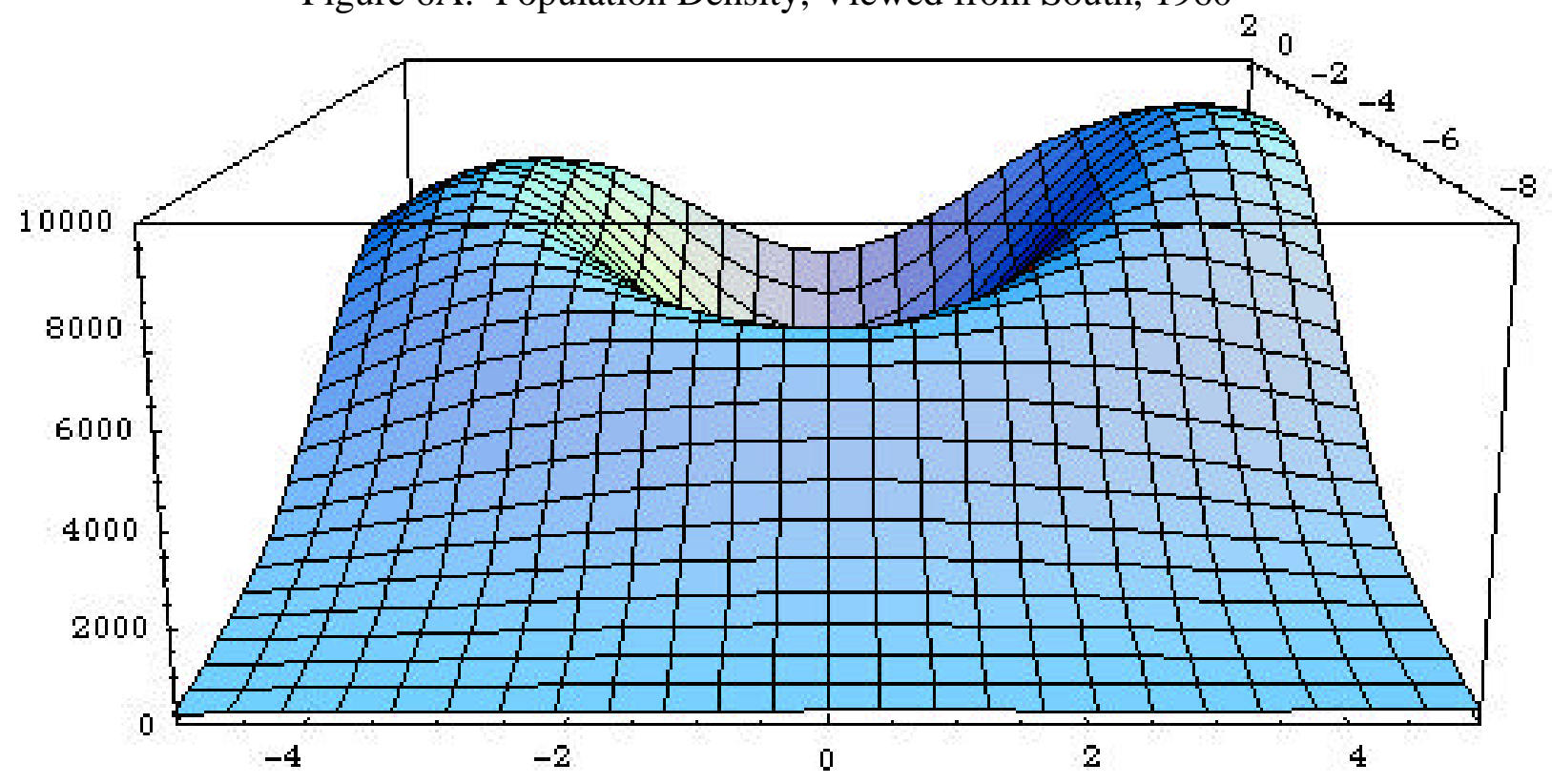

Figure 6B: Population Density, Viewed from South, 1980

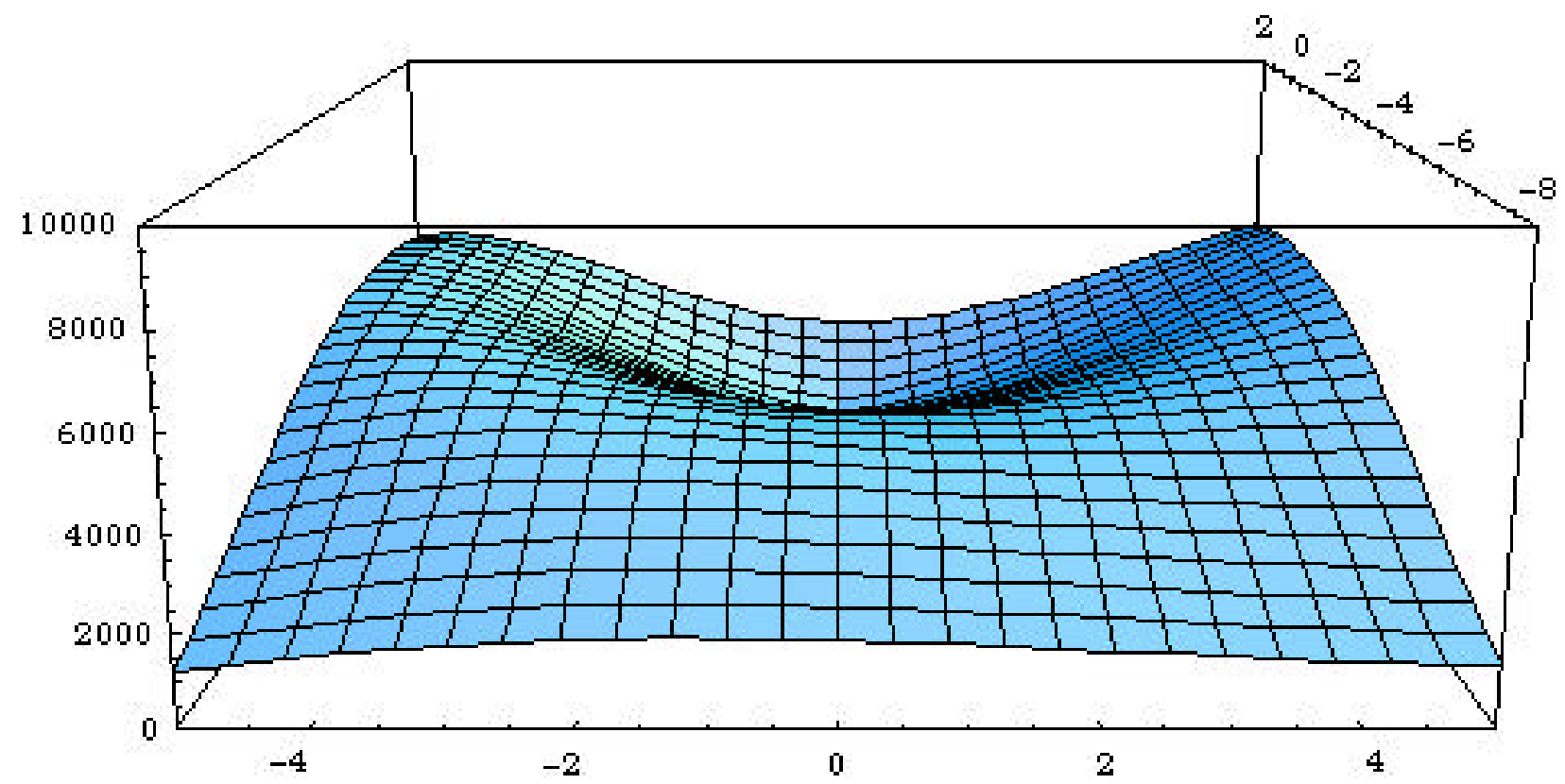

Notes: The center of the graph is at Public Square. The height of the surface represents an estimate of residential population density (population per square kilometer). Distances along the $\mathrm{x}$ and $\mathrm{y}$ axes are in terms of miles. The graphed functions represent the regression estimates reported in appendix table 2.

Sources: Tract-level population data are from the published volumes of the federal Census of Population in 1960 and 1980. 
Figure 7A: Change in Population Density, Viewed from Southeast, 1960 to 1980

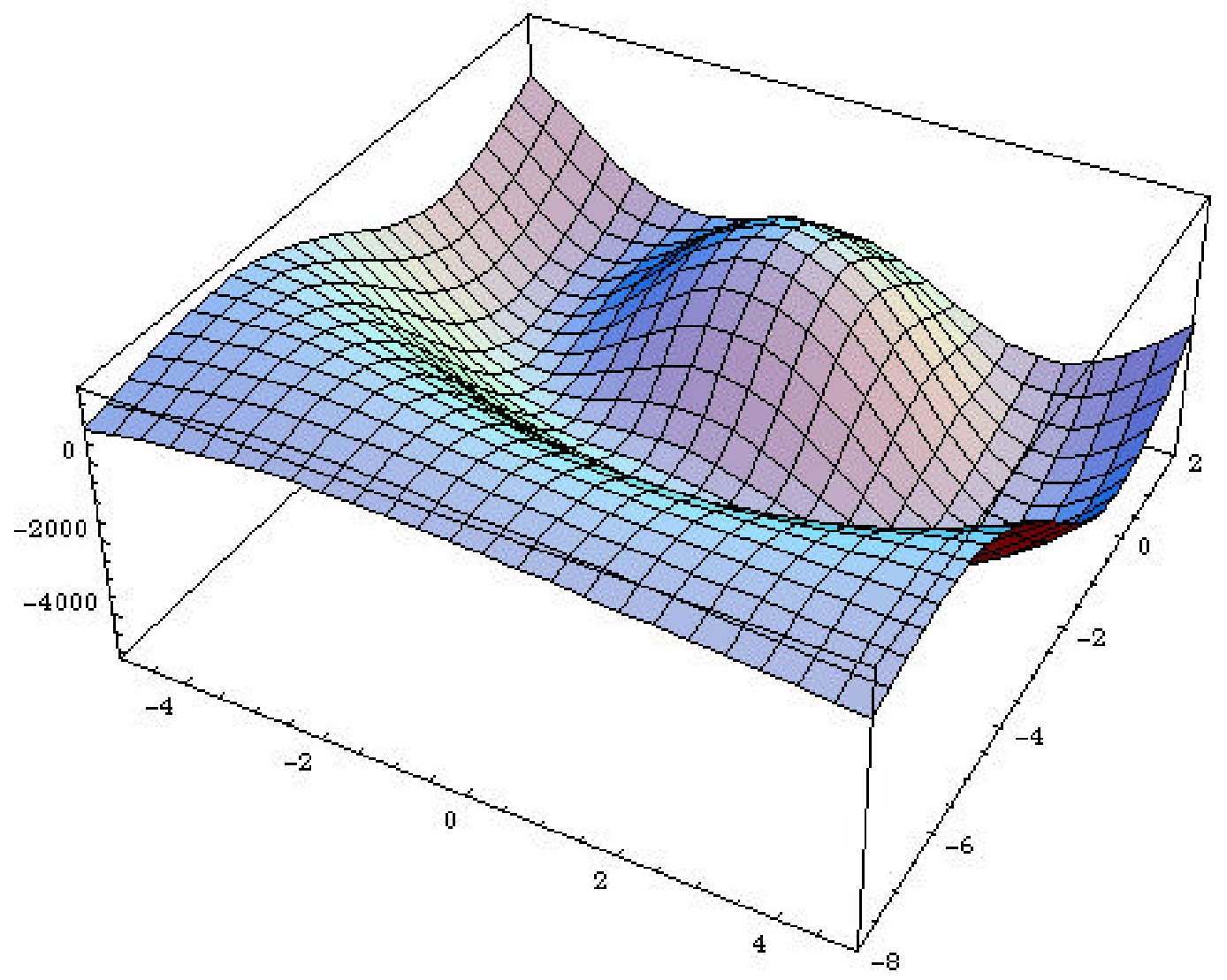

Figure 7B: Change in Population Density, Viewed from North, 1960-1980

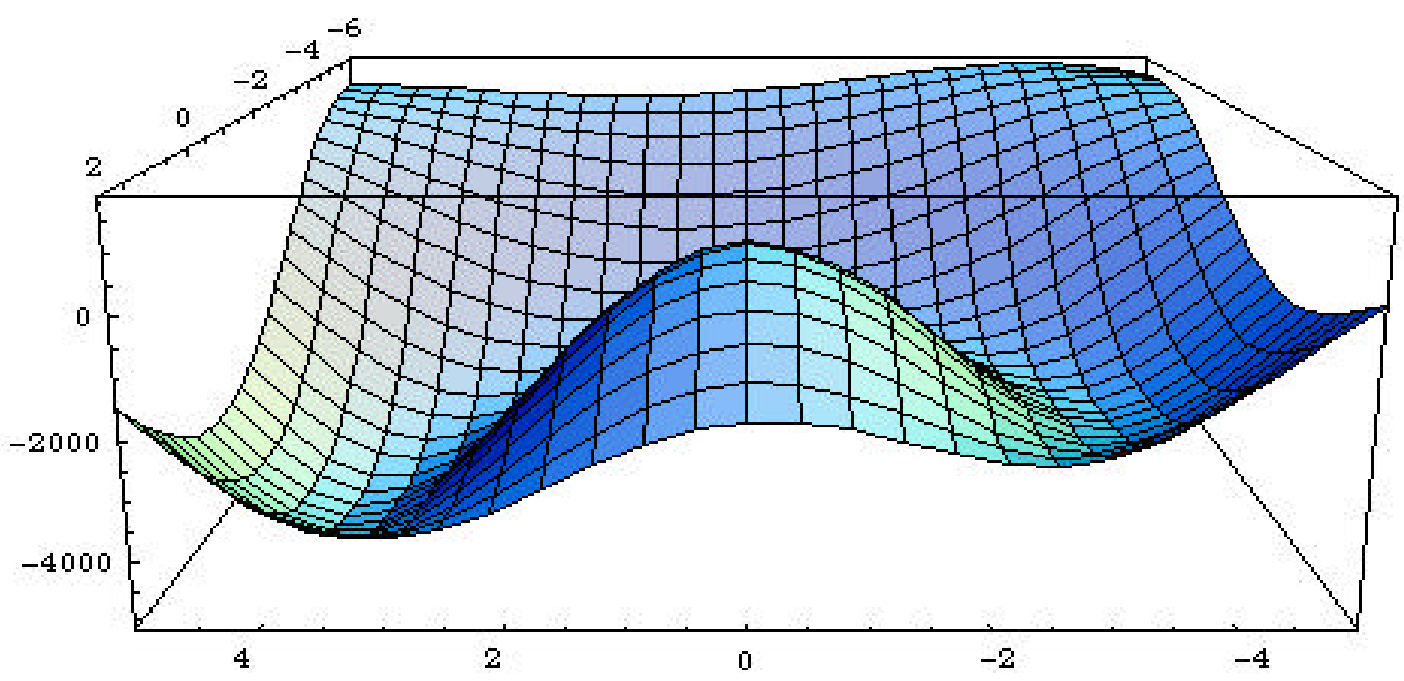

Notes: The center of the graph is Public Square. The height of the graphed surface is the difference between the estimated density functions for 1960 and 1980 (measured in thousands of residents per square kilometer). Distances along the $\mathrm{x}$ and $\mathrm{y}$ axes are measured in terms of miles. The underlying regression results are reported in appendix table 2.

Sources: Tract-level population data are from the volumes of the federal Census of Population for 1960 and 1980. 